\title{
PENGARUH MOTIVASI, DISIPLIN, KEPUASAN KERJA, DAN IKLIM PERUSAHAAN \\ TERHADAP KINERJA KARYAWAN \\ PADA PT. PROFAB INDONESIA
}

\section{TESIS}

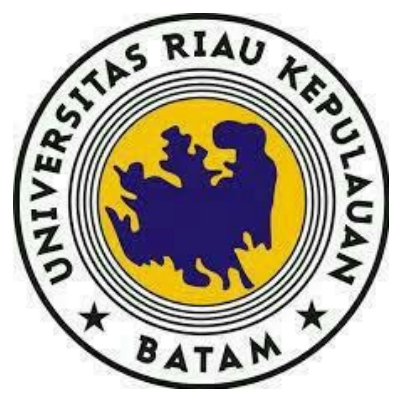

DECKY ANTONY KIFTA

NPM: 16180020

\author{
PROGRAM STUDI MAGISTER MANAJEMEN \\ PROGRAM PASCASARJANA \\ UNIVERSITAS RIAU KEPULAUAN \\ BATAM \\ 2019
}




\title{
PENGARUH MOTIVASI, DISIPLIN, KEPUASAN \\ KERJA, DAN IKLIM PERUSAHAAN \\ TERHADAP KINERJA KARYAWAN \\ PADA PT. PROFAB INDONESIA
}

\section{TESIS}

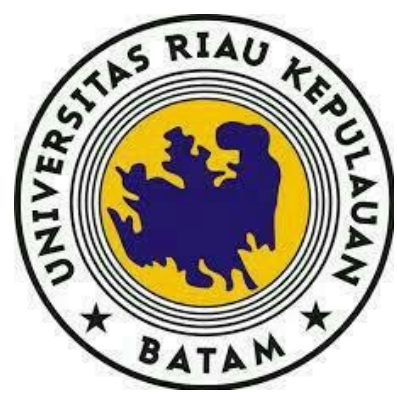

\section{DECKY ANTONY KIFTA}

NPM: 16180020

Tesis ini disusun untuk Memenuhi Sebagian Persyaratan

Mendapatkan Gelar Magister dalam Program Studi Magister Manajemen

\author{
PROGRAM STUDI MAGISTER MANAJEMEN \\ PROGRAM PASCASARJANA \\ UNIVERSITAS RIAU KEPULAUAN \\ BATAM \\ 2019
}




\begin{abstract}
ABSTRAK
Tujuan penelitian ini adalah untuk mengetahui pengaruh motivasi, disiplin, kepuasan kerja dan iklim perusahaan terhadap kinerja karyawan pada PT. Profab Indonesia. Terdapat empat variabel yang dipercaya mempengaruhi variabel kinerja karyawan, yaitu motivasi, disiplin, kepuasan kerja dan iklim perusahaan. Kemudian untuk memperoleh data yang diperlukan, selama penelitian penulis menggunakan metode wawancara, observasi, dan kuesioner. Kuesioner yang dibuat mengacu pada keempat variabel bebas dan satu variabel terikat itu dibagikan kepada kuesioner. Sebanyak 200 orang karyawan terpilih sebagai responden yang mengisi kuesioner, dan data yang diperoleh melalui kuesioner kemudian dianalisis dengan menggunakan program SPSS. Pengujian yang dilakukan meliputi uji statistik yaitu seperti uji prasyarat analisis (normalitas), uji t, uji F, persamaan regresi dan koefisien determinasi. Hasil yang diperoleh dari uji statistik tersebut kemudian disimpulkan, dan dibuktikan bahwa adapengaruh signifikan antara motivasi, disiplin, kepuasan kerja dan iklim perusahaan terhadap kinerja karyawan baik secara parsial maupun simultan. Hal ini ditunjukkan dengan nilai koefisien korelasi (nilai R) sebesar 0,919 atau 'sangat kuat', dan nilai adjusted $R$ square sebesar 0,841 , atau $84,1 \%$, maka hal ini berarti bahwa pengaruh motivasi, disiplin, kepuasan kerja dan iklim perusahaan sangat kuat terhadap kinerja karyawan dengan persentase sebesar $84,1 \%$.
\end{abstract}

Kata kunci : Motivasi, Disiplin, Kepuasan Kerja, Iklim Perusahaan, Kinerja Karyawan 


\section{DAFTAR ISI}

Halaman

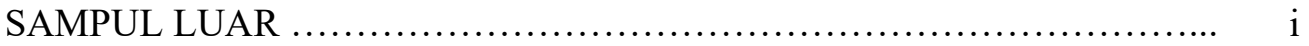

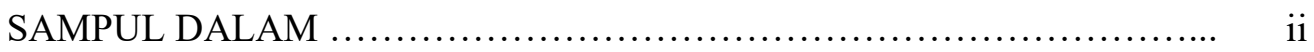

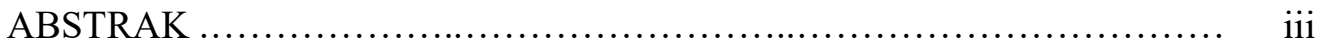

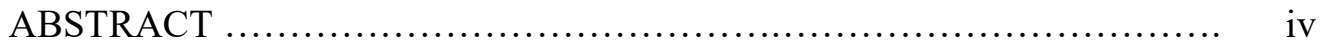

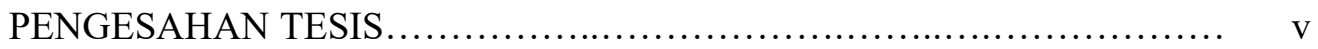

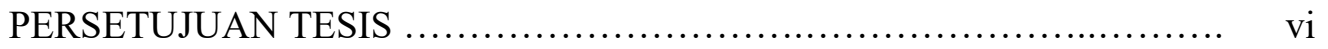

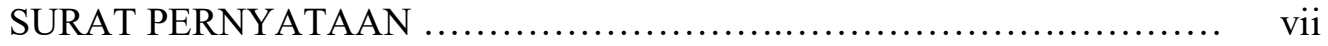

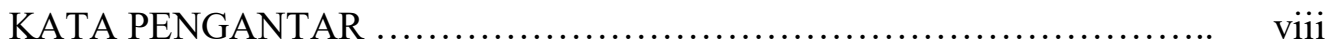

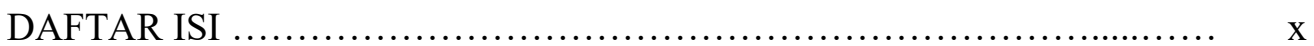

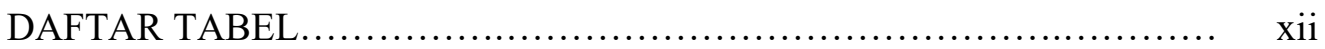

DAFTAR GAMBAR ….............................................. xiii

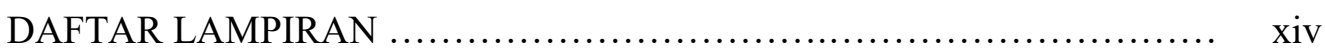

BAB I PENDAHULUAN ...................................... 1

A. Latar Belakang Masalah ................................. 1

B. Batasan Masalah ..................................... 7

C. Rumusan Masalah ........................................ 7

D. Tujuan Penelitian ............................................ 8

E. Manfaat Penelitian ................................... 8

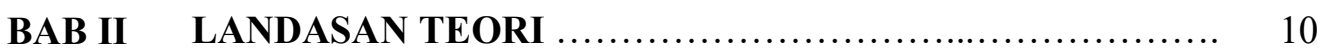

A. Landasan Teori ......................................... 10

1. Motivasi........................................... 10

2. Disiplin............................................ 15

3. Kepuasan Kerja................................... 24

4. Iklim Perusahaan .................................... 29

5. Kinerja Karyawan ................................ 33

B. Kerangka Pemikiran ..................................... 37

C. Hasil Penelitian Terdahulu .............................. 39

D. Hipotesis ............................................ 42

BAB III METODE PENELITIAN ................................. 43

A. Jenis dan Desain Penelitian ............................... 43

1. Jenis Penelitian....................................... 43

2. Desain Penelitian ................................... 43

B. Populasi dan Sampel .................................... 44

1. Populasi............................................ 44

2. Sampel ......................................... 45

C. Variabel Penelitian .................................... 46

1. Identifikasi Variabel ................................... 46

2. Definisi Operasional .............................. 47 
D. Instrumen Penelitian........................................ 53

E. Teknik Analisis Instrumen................................... 54

1. Uji Kesahihan Instrumen (Validitas) .................. 54

2. Uji Kehandalan Instrumen (Reliabilitas) ................ 59

F. Teknik Analisis Data .................................... 61

1. Uji Asumsi Klasik ................................. 61

2. Uji Hipotesis ................................... 63

BAB IV HASIL PENELITIAN DAN PEMBAHASAN ................. 68

A. Hasil Penelitian ......................................... 68

1. Karakteristik Responden ........................... 68

2. Deskripsi Data .................................... 71

3. Analisis Data ...................................... 77

B. Pembahasan ............................................ 93

1. Pengaruh Motivasi Terhadap Kinerja Karyawan .......... 93

2. Pengaruh Disiplin Terhadap Kinerja Karyawan ........... 94

3. Pengaruh Kepuasan Kerja Terhadap Kinerja Karyawan ... 95

4. Pengaruh Iklim Perusahaan Terhadap Kinerja Karyawan .. 95

5. Pengaruh Motivasi, Disiplin, Kepuasan Kerja, dan Iklim 96

Perusahaan Terhadap Kinerja Karyawan................. 96

6. Pembuktian Hipotesis ............................. 97

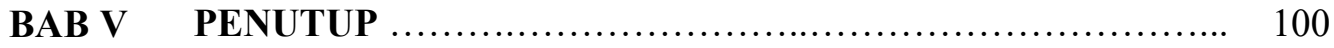

A. Kesimpulan ........................................... 100

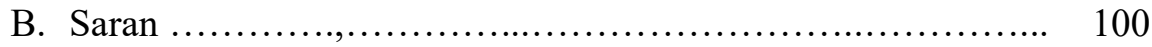

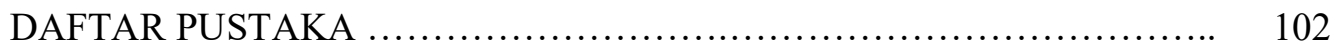

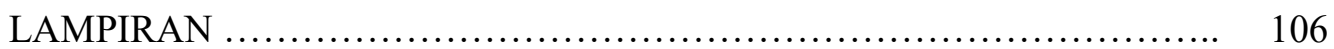




\section{DAFTAR TABEL}

Halaman

1. Tabulasi Penentuan Nilai Pencapaian ........................... 3

2. Capaian Motivasi Karyawan ................................ 4

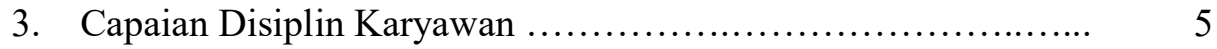

4. Capaian Kepuasan Kerja .................................... 6

5. Capaian Iklim Perusahaan ................................... 6

6. Capaian Kinerja Karyawan .................................. 7

7. Daftar Penelitian-Penelitian Terdahulu ........................ 41

8. Jumlah Pembagian Sampel .................................... 47

9. Definisi Operasional Variabel Motivasi.......................... 48

10. Definisi Operasional Variabel Disiplin ........................ 49

11. Definisi Operasional Variabel Kepuasan Kerja.................... $\quad 50$

12. Definisi Operasional Variabel Iklim Perusahaan.................. 51

13. Definisi Operasional Variabel Kinerja Karyawan ............... 52

14. Hasil Uji Validitas Variabel Motivasi ........................... 56

15. Hasil Uji Validitas Variabel Disiplin .......................... 57

16. Hasil Uji Validitas Variabel Kepuasan Kerja .................... 57

17. Hasil Uji Validitas Variabel Iklim Perusahaan ................... 58

18. Hasil Uji Validitas Variabel Kinerja Karyawan ................... 59

19. Hasil Pengujian Reliabilitas .................................... 60

20. Derajat Reliabilitas ......................................... $\quad 60$

21. Distribusi Pendidikan Terakhir ................................. 68

22. Distribusi Masa Kerja ...................................... 69

23. Distribusi Usia .............................................. $\quad 70$

24. Distribusi Jenis Kelamin ..................................... 70

25. Data Motivasi ............................................... 71

26. Data Disiplin ................................................. 72

27. Data Kepuasan Kerja .............................................. 74

28. Data Iklim Perusahaan ....................................... $\quad 75$

29. Data Kinerja Karyawan ................................... 76

30. Hasil Uji Normalitas Residual .................................. 79

31. Nilai Signifikansi Defiation from Linearity .................... 80

32. Model Summary ............................................. 81

33. Estimasi Hasil Uji Multikolinearitas .......................... 82

34. Koefisien .................................................. 84

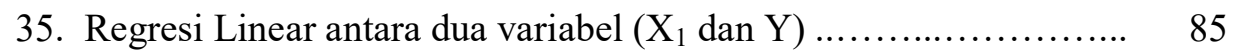

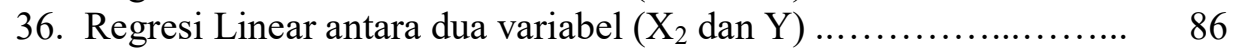

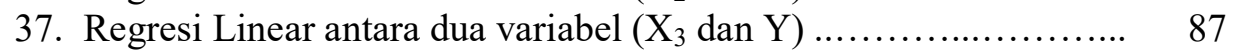

38. Regresi Linear antara dua variabel $\left(\mathrm{X}_{4}\right.$ dan $\left.\mathrm{Y}\right) \ldots \ldots \ldots \ldots \ldots \ldots \ldots . \ldots \ldots$

39. Anova .................................................. 90

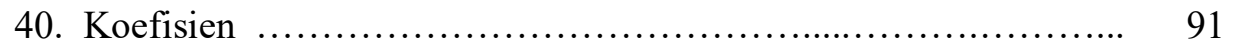

41. Hasil Estimasi Regresi Berganda.............................. 93 


\section{DAFTAR GAMBAR}

Halaman

1. Kerangka Konseptual ...................................... 38

2. Kerangka Operasional .......................................... 44

3. Histogram dan Poligon Data Motivasi ........................... 72

4. Histogram dan Poligon Disiplin ............................... 73

5. Histogram dan Poligon Kepuasan Kerja ........................ 74

6. Histogram dan Poligon Iklim Perusahaan ......................... 76

7. Histogram dan Poligon Kinerja Karyawan ...................... 77

8. Normal P-P Plot of Regression Standardized Residual ............. $\quad 78$

9. Plot Hasil Uji Heteroskedastisitas Variabel ......................... 83 


\section{DAFTAR LAMPIRAN}

Halaman

1. Riwayat Hidup .............................................. 106

2. Kuesioner Penelitian ......................................... 107

3. Surat Permohonan Izin Penelitian ............................ 113

4. Data Responden Motivasi ...................................... 114

5. Data Responden Disiplin ...................................... 119

6. Data Responden Kepuasan Kerja .............................. 124

7. Data Responden Iklim Perusahaan ............................ 129

8. Data Responden Kinerja Karyawan ........................... 133

9. Total Skor Data Responden ................................ 137

10. Tabel Korelasi Motivasi ....................................... 142

11. Tabel Korelasi Disiplin ....................................... 144

12. Tabel Korelasi Kepuasan Kerja ................................ 148

13. Tabel Korelasi Iklim Perusahaan ............................... 150

14. Tabel Korelasi Kinerja Karyawan ............................... 154

15. Hasil Uji One-Sample Kolmogorov-Smirnov ..................... 158

16. Tabel Reliabiltas .............................................. 159

17. Regresi Berganda .......................................... 160

18. Tabel Frequency Variabel Motivasi ............................ 165

19. Tabel Frequency Variabel Disiplin ............................. 167

20. Tabel Frequency Variabel Kepuasan Kerja....................... 169

21. Tabel Frequency Variabel Iklim Perusahaan....................... 171

22. Tabel Frequency Variabel Kinerja Karyawan..................... 173 


\section{BAB I \\ PENDAHULUAN}

\section{A. Latar Belakang}

Pada berbagai bidang khususnya kehidupan berorganisasi, faktor manusia merupakan masalah utama dalam setiap kegiatan yang berhubungan dengan organisasi. Organisasi dalam hal ini diwakilkan oleh perusahaan merupakan kesatuan sosial yang dikoordinasikan secara sadar dengan sebuah batasan yang reaktif yang dapat diidentifikasikan, dan yang bekerja secara terus menerus untuk mencapai tujuan tertentu (Robbins, 2013:5). Semua tindakan yang diambil dalam setiap kegiatan diprakarsai dan ditentukan oleh manusia yang menjadi anggota organisasi atau perusahaan tersebut. Perusahaan membutuhkan adanya faktor sumber daya manusia yang potensial baik sebagai pemimpin maupun karyawan dengan pola tugas dan pengawasan yang merupakan penentu tercapainya tujuan perusahaan tersebut.

Sumber daya manusia merupakan faktor sentral dalam organisasi ataupun perusahaan. Agar aktivitas perusahaan dapat berjalan dengan baik, maka perusahaan harus memiliki karyawan yang berpengetahuan dan berketrampilan tinggi serta mampu mengelola perusahaan seoptimal mungkin sehingga kinerja karyawan dan perusahaan meningkat. Amstrong dan Baron (1998) dalam Wibowo (2017:2) mendefinisikan kinerja sebagai hasil pekerjaan yang mempunyai hubungan kuat dengan tujuan strategis organisasi, kepuasan pelanggan dan memberikan kontribusi ekonomi bagi karyawan dan perusahaan. Kinerja yang baik adalah kinerja yang optimal, yaitu kinerja yang sesuai standar organisasi atau perusahaan dan yang mendukung tercapainya tujuan perusahaan. Perusahaan yang baik adalah perusahaan yang berusaha meningkatkan kemampuan sumber daya manusianya, karena hal tersebut merupakan faktor kunci untuk meningkatkan kinerja karyawan. 
PT. Profab Indonesia adalah sebuah perusahaan yang bergerak dalam bidang fabrikasi dan penunjang industri pertambangan minyak dan gas atau 'oil and gas industry'. Perusahaan ini merupakan perusahaan nasional dengan modal asing (PMA) yang telah berdiri sejak tahun 1998 di Batam, dan terus berkembang hingga sekarang ini. Pada tahun 2014 keseluruhan saham perusahaan kemudian dimiliki oleh perusahaan asing asal Amerika yang bernama National Oilwell Varco (NOV), NOV sendiri adalah perusahaan yang telah berdiri lama dan bergerak di bidang explorasi minyak dan gas bumi dan telah memiliki cabang perusahaan di banyak negara.

Permasalahan yang terjadi adalah setiap perusahaan mengharapkan agar karyawannya dapat berkinerja dengan baik. Informasi mengenai kinerja karyawan dapat diketahui apakah seorang karyawan dapat bekerja dengan baik atau tidak yang dilihat dari kategori penilaian yang dibandingkan antara tolok ukur atau standar penilaian kinerja perusahaan dengan kinerja karyawan. Sehingga dapat diartikan bahwa penilaian yang semakin tinggi menjadi indikasi bahwa kinerja karyawan tersebut mampu memenuhi harapan kinerja perusahaan. Penilaian yang dilakukan selama lima tahun terakhir membuktikan bahwa peningkatan kinerja masih diperlukan untuk mencapai kinerja yang maksimal.

Peningkatan kinerja karyawan akan membawa kemajuan bagi perusahaan dan kemampuan untuk dapat bertahan dalam persaingan bisnis yang cenderung tidak stabil. Oleh karena itu upaya-upaya untuk meningkatkan kinerja karyawan merupakan tantangan manajemen yang paling serius karena keberhasilan untuk mencapai tujuan dan kelangsungan hidup perusahaan tergantung pada kualitas kinerja sumber daya manusia yang ada di dalamnya. Terdapat beberapa faktor positif yang dapat meningkatkan kinerja karyawan, yang pertama adalah motivasi, kemudian disiplin, serta kepuasan kerja dan faktor-faktor lain seperti iklim perusahaan terhadap kinerja karyawan yang merupakan aset bagi perusahaa.

Berdasarkan uraian di atas dan dengan melihat permasalahan serta kendala yang dihadapi karyawan dalam pekerjaannya, yaitu mereka yang 
tidak mencapai output kinerja maksimal yang telah ditetapkan perusahaan, serta untuk mencapai predikat tertentu yang ditentukan perusahaan. Maka dengan demikian akan menjadi sangat penting dan dipandang perlu untuk melakukan sebuah penelitian mengenai bagaimana meningkatkan kinerja karyawan dengan memperhatikan faktor-faktor motivasi, disiplin, kepuasan kerja dan iklim perusahaan.

Data yang diperoleh dari departemen personalia atau human resources terhadap variabel-variabel motivasi, disiplin, kepuasan kerja, iklim perusahaan dan kinerja karyawan dari PT. Profab Indonesia, sebagai variabel yang digunakan dalam penelitian ini, dalam kurun waktu lima tahun terakhir masih belum memuaskan karena rata-rata nilainya masih dalam grade 4 dari grade 5 yang ditargetkan. Berikut ini adalah tabulasi nilai capaian (grade) dari masing-masing pencapaian yang diinginkan.

Tabel 1. Tabulasi Penentuan Nilai Pencapaian

\begin{tabular}{|c|c|c|}
\hline Grade & Nilai & Kategori \\
\hline 5 & $85-100$ & Memuaskan \\
\hline 4 & $70-84$ & Baik \\
\hline 3 & $55-69$ & Cukup \\
\hline 2 & $40-54$ & Kurang Baik \\
\hline 1 & $<40$ & Tidak Baik \\
\hline
\end{tabular}

Sumber: Data olahan, 2019.

Sebagaimana dijelaskan pada Tabel 1 di atas bahwa nilai-nilai pencapaian dari variabel-variabel motivasi, disiplin, kepuasan kerja, iklim perusahaan dan kinerja karyawan sebelumnya diperlukan sebagai latar belakang penelitian ini maka di bawah ini adalah tabulasi pencapain dari variabel-variabel di atas selama kurun waktu lima tahun terakhir yaitu dari tahun 2013 sampai tahun 2017.

Dari Tabel 2 di bawah nilai pencapaian motivasi rata-rata yang diperoleh pada tiap tahun berfluktuatif dan titik terendah ada pada tahun 2016 yaitu sebesar 74. Sedangkan departemen Produksi (Production) sebagai 
departemen yang terbesar dengan jumlah karyawan 310 orang memiliki ratarata pencapaian yang paling rendah yaitu 66,6. Secara keseluruhan pencapaian rata-rata selama lima tahun monitoring ada pada grade 4 dengan nilai rata-rata sebesar 78,64. Hal ini menyimpulkan bahwa perbaikan masih perlu dilakukan dalam sektor atau variabel motivasi ini.

Tabel 2. Capaian Motivasi Karyawan PT. Profab Indonesia periode Tahun 2013 s/d Tahun 2017

\begin{tabular}{|c|c|c|c|c|c|c|c|c|}
\hline \multirow{2}{*}{ No. } & \multirow{2}{*}{ Departemen } & \multicolumn{5}{|c|}{ Tahun } & \multirow{2}{*}{$\begin{array}{l}\text { Rata- } \\
\text { rata }\end{array}$} & \multirow{2}{*}{$\begin{array}{c}\text { Jumlah } \\
\text { karyawan }\end{array}$} \\
\hline & & 2013 & 2014 & 2015 & 2016 & 2017 & & \\
\hline 1 & Production & 72 & 68 & 60 & 55 & 78 & 66,6 & 310 \\
\hline 2 & Quality & 88 & 78 & 90 & 77 & 85 & 83,6 & 20 \\
\hline 3 & Engineering & 90 & 85 & 78 & 80 & 87 & 84 & 20 \\
\hline 4 & $H S E$ & 84 & 80 & 76 & 81 & 70 & 78,1 & 20 \\
\hline 5 & Maintenance & 74 & 81 & 84 & 70 & 68 & 75,4 & 10 \\
\hline 6 & GA Admin & 80 & 82 & 85 & 78 & 78 & 80,6 & 10 \\
\hline 7 & Finance & 80 & 84 & 90 & 77 & 80 & 82,2 & 10 \\
\hline & Total & 568 & 558 & 563 & 518 & 546 & \multirow{2}{*}{\multicolumn{2}{|c|}{78,64}} \\
\hline & Rata-rata & 81,1 & 79,7 & 80,4 & 74 & 78 & & \\
\hline
\end{tabular}

Sumber: Data olahan, 2019.

Dari Tabel 3 di bawah nilai pencapaian disiplin rata-rata yang diperoleh pada tiap tahun berfluktuatif dan titik terendah ada pada tahun 2016 yaitu sebesar 78,1. Sedangkan departemen Produksi (Production) sebagai departemen yang terbesar dengan jumlah karyawan 310 orang memiliki ratarata pencapaian yang paling rendah yaitu 75 . Secara keseluruhan pencapaian rata-rata selama lima tahun monitoring ada pada grade 4 dengan nilai ratarata sebesar 81,16 . Hal ini menyimpulkan bahwa perbaikan masih perlu dilakukan dalam sektor atau variabel disiplin ini.

Dari Tabel 4 di bawah nilai pencapaian kepuasan kerja rata-rata yang diperoleh pada tiap tahun berfluktuatif dan titik terendah ada pada tahun 2015 yaitu sebesar 73,4. Sedangkan departemen HSE (Health, Safety \& Environment) dengan jumlah karyawan 20 orang memiliki rata-rata 
pencapaian yang paling rendah yaitu 75,8 . Secara keseluruhan pencapaian rata-rata selama lima tahun monitoring ada pada grade 4 dengan nilai ratarata sebesar 78,88. Hal ini menyimpulkan bahwa perbaikan masih perlu dilakukan dalam sektor atau variabel kepuasan kerja ini.

Dari Tabel 5 di bawah, nilai pencapaian iklim perusahaan rata-rata yang diperoleh pada tiap tahun berfluktuatif dan titik terendah ada pada tahun 2013 yaitu sebesar 77,7. Sedangkan departemen Maintenance dengan jumlah karyawan 10 orang memiliki rata-rata pencapaian yang paling rendah yaitu 71,2. Secara keseluruhan pencapaian rata-rata selama lima tahun monitoring ada pada grade 4 dengan nilai rata-rata sebesar 80,56. Hal ini menyimpulkan bahwa perbaikan masih perlu dilakukan dalam sektor atau variabel iklim perusahaan ini.

Tabel 3. Capaian Disiplin Karyawan PT. Profab Indonesia periode Tahun 2013 s/d Tahun 2017

\begin{tabular}{|c|c|c|c|c|c|c|c|c|}
\hline \multirow{2}{*}{ No. } & \multirow{2}{*}{ Departemen } & \multicolumn{5}{|c|}{ Tahun } & \multirow{2}{*}{$\begin{array}{l}\text { Rata- } \\
\text { rata }\end{array}$} & \multirow{2}{*}{$\begin{array}{c}\text { Jumlah } \\
\text { karyawan }\end{array}$} \\
\hline & & 2013 & 2014 & 2015 & 2016 & 2017 & & \\
\hline 1 & Production & 70 & 78 & 68 & 80 & 79 & 75 & 310 \\
\hline 2 & Quality & 80 & 84 & 90 & 80 & 86 & 84 & 20 \\
\hline 3 & Engineering & 90 & 85 & 79 & 74 & 78 & 81,2 & 20 \\
\hline 4 & $H S E$ & 88 & 78 & 90 & 75 & 80 & 82,2 & 20 \\
\hline 5 & Maintenance & 84 & 90 & 87 & 78 & 80 & 83,8 & 10 \\
\hline 6 & GA Admin & 78 & 78 & 80 & 76 & 81 & 78,6 & 10 \\
\hline 7 & Finance & 80 & 82 & 90 & 84 & 82 & 83,6 & 10 \\
\hline & Total & 570 & 575 & 584 & 547 & 566 & \multirow{2}{*}{\multicolumn{2}{|c|}{81,16}} \\
\hline & Rata-rata & 81,4 & 82,1 & 83.4 & 78,1 & 80,8 & & \\
\hline
\end{tabular}

Sumber: Data olahan, 2019.

Dari Tabel 6 di bawah nilai pencapaian kinerja karyawan rata-rata yang diperoleh pada tiap tahun berfluktuatif dan titik terendah ada pada tahun 2013 yaitu sebesar 82,4. Sedangkan departemen Produksi (Production) sebagai departemen terbesar di perusahaan, dengan jumlah anggota sebanyak 310 orang, memiliki rata-rata pencapaian yang paling rendah yaitu 74,6. Secara keseluruhan pencapaian rata-rata selama lima tahun monitoring 
ada pada grade 4 dengan nilai rata-rata sebesar 83,98. Hal ini menyimpulkan bahwa perbaikan masih perlu dilakukan dalam sektor atau variabel kinerja karyawan ini.

\section{Tabel 4. Capaian Kepuasan Kerja Karyawan PT. Profab Indonesia} periode Tahun 2013 s/d Tahun 2017

\begin{tabular}{|c|c|c|c|c|c|c|c|c|}
\hline \multirow{2}{*}{ No. } & \multirow{2}{*}{ Departemen } & \multicolumn{5}{|c|}{ Tahun } & \multirow{2}{*}{$\begin{array}{l}\text { Rata- } \\
\text { rata }\end{array}$} & \multirow{2}{*}{$\begin{array}{c}\text { Jumlah } \\
\text { karyawan }\end{array}$} \\
\hline & & 2013 & 2014 & 2015 & 2016 & 2017 & & \\
\hline 1 & Production & 80 & 78 & 76 & 82 & 70 & 77,2 & 310 \\
\hline 2 & Quality & 75 & 80 & 69 & 84 & 72 & 76 & 20 \\
\hline 3 & Engineering & 82 & 76 & 72 & 79 & 74 & 76,6 & 20 \\
\hline 4 & $H S E$ & 72 & 81 & 73 & 81 & 72 & 75,8 & 20 \\
\hline 5 & Maintenance & 81 & 74 & 70 & 90 & 80 & 79 & 10 \\
\hline 6 & GA Admin & 90 & 81 & 73 & 88 & 87 & 83,8 & 10 \\
\hline 7 & Finance & 85 & 82 & 81 & 82 & 90 & 84 & 10 \\
\hline & Total & 565 & 552 & 514 & 586 & 545 & \multirow{2}{*}{\multicolumn{2}{|c|}{78,88}} \\
\hline & Rata-rata & 80,7 & 78,8 & 73,4 & 83,7 & 77,8 & & \\
\hline
\end{tabular}

Sumber: Data olahan, 2019.

Tabel 5. Capaian Iklim Perusahaan PT. Profab Indonesia periode Tahun 2013 s/d Tahun 2017

\begin{tabular}{|c|c|c|c|c|c|c|c|c|}
\hline \multirow{2}{*}{ No. } & \multirow{2}{*}{ Departemen } & \multicolumn{5}{|c|}{ Tahun } & \multirow{2}{*}{$\begin{array}{l}\text { Rata- } \\
\text { rata }\end{array}$} & \multirow{2}{*}{$\begin{array}{l}\text { Jumlah } \\
\text { karyawan }\end{array}$} \\
\hline & & 2013 & 2014 & 2015 & 2016 & 2017 & & \\
\hline 1 & Production & 77 & 80 & 84 & 82 & 78 & 80,2 & 310 \\
\hline 2 & Quality & 80 & 84 & 90 & 87 & 79 & 84 & 20 \\
\hline 3 & Engineering & 78 & 81 & 88 & 87 & 90 & 84.8 & 20 \\
\hline 4 & HSE & 80 & 76 & 89 & 77 & 78 & 80 & 20 \\
\hline 5 & Maintenance & 70 & 72 & 68 & 71 & 75 & 71,2 & 10 \\
\hline 6 & GA Admin & 78 & 80 & 80 & 82 & 84 & 80,8 & 10 \\
\hline 7 & Finance & 81 & 79 & 85 & 89 & 82 & 83,2 & 10 \\
\hline & Total & 544 & 552 & 584 & 575 & 566 & \multirow{2}{*}{\multicolumn{2}{|c|}{80,56}} \\
\hline & Rata-rata & 77.7 & 78,8 & 83,4 & 82,1 & 80,8 & & \\
\hline
\end{tabular}

Sumber: Data olahan, 2019. 
Tabel 6. Capaian Kinerja Karyawan PT. Profab Indonesia periode Tahun 2013 s/d Tahun 2017

\begin{tabular}{|c|c|c|c|c|c|c|c|c|}
\hline \multirow{2}{*}{ No. } & \multirow{2}{*}{ Departemen } & \multicolumn{5}{|c|}{ Tahun } & \multirow{2}{*}{$\begin{array}{l}\text { Rata- } \\
\text { rata }\end{array}$} & \multirow{2}{*}{$\begin{array}{c}\text { Jumlah } \\
\text { karyawan }\end{array}$} \\
\hline & & 2013 & 2014 & 2015 & 2016 & 2017 & & \\
\hline 1 & Production & 77 & 72 & 76 & 70 & 78 & 74,6 & 310 \\
\hline 2 & Quality & 80 & 88 & 84 & 87 & 79 & 83,6 & 20 \\
\hline 3 & Engineering & 82 & 90 & 87 & 88 & 82 & 85,8 & 20 \\
\hline 4 & $H S E$ & 80 & 87 & 89 & 85 & 80 & 84,2 & 20 \\
\hline 5 & Maintenance & 80 & 85 & 87 & 90 & 84 & 85,2 & 10 \\
\hline 6 & GA Admin & 90 & 88 & 87 & 85 & 89 & 87,8 & 10 \\
\hline 7 & Finance & 88 & 85 & 87 & 86 & 88 & 86,8 & 10 \\
\hline & Total & 577 & 595 & 597 & 591 & 580 & \multirow{2}{*}{\multicolumn{2}{|c|}{83,98}} \\
\hline & Rata-rata & 82,4 & 85 & 85,3 & 84,4 & 82,8 & & \\
\hline
\end{tabular}

Sumber: Data olahan, 2019.

\section{B. Batasan Masalah}

Untuk membatasi lingkup pembahasan agar sesuai dengan tujuan penelitian, maka penulis memberikan batasan pembahasan sebagai berikut:

1. Penelitian dilakukan di PT. Profab Indonesia pada karyawan kantor dan lapangan.

2. Pengambilan data kuesioner dilakukan dengan menggunakan sampel.

3. Pembahasan menggunakan statistik deskriptif dan metode-metode pada program software SPSS.

\section{Rumusan Masalah}

Berdasarkan latar belakang yang telah diuraikan di atas maka dapat dirumuskan masalah-masalah yang akan diteliti adalah sebagai berikut:

1. Apakah motivasi berpengaruh terhadap kinerja karyawan pada PT. Profab Indonesia?

2. Apakah disiplin berpengaruh terhadap kinerja karyawan pada PT. Profab Indonesia?

3. Apakah kepuasan kerja berpengaruh terhadap kinerja karyawan pada PT. Profab Indonesia?

4. Apakah iklim perusahaan berpengaruh terhadap kinerja karyawan pada PT. Profab Indonesia? 
5. Apakah motivasi, disiplin, kepuasan kerja dan iklim perusahaan secara bersama-sama berpengaruh terhadap kinerja karyawan pada PT. Profab Indonesia?

\section{Tujuan Penelitian}

Sesuai dengan pokok permasalahan di atas, maka disusun tujuan penelitian ini sebagai berikut:

1. Untuk mengetahui pengaruh motivasi terhadap kinerja karyawan pada PT. Profab Indonesia.

2. Untuk mengetahui pengaruh disiplin terhadap kinerja karyawan pada PT. Profab Indonesia.

3. Untuk mengetahui pengaruh kepuasan kerja terhadap kinerja karyawan pada PT. Profab Indonesia.

4. Untuk mengetahui pengaruh iklim perusahaan terhadap kinerja karyawan pada PT. Profab Indonesia.

5. Untuk mengetahui pengaruh motivasi, disiplin, kepuasan kerja dan iklim perusahaan secara bersama-sama terhadap kinerja karyawan pada PT. Profab Indonesia.

\section{E. Manfaat Penelitian}

Manfaat yang dapat diperoleh dari proses penelitian serta analisis data dalam pengujian hipotesis penelitian ini diharapkan dapat memberikan kontribusi teoritis dan praktis kepada perusahaan, yaitu:

1. Kontribusi teoritis

Kontribusi yang memperkaya bukti empiris pengaruh motivasi, disiplin, kepuasan kerja dan iklim perusahaan terhadap kinerja karyawan pada PT. Profab Indonesia. Kontribusi teoritis ini dapat dikembangkan oleh para akademisi untuk mengembangkan penelitianpenelitian sejenis selanjutnya dan juga memperkaya keilmuan dari akademisi yang menggunakannya.

2. Kontribusi praktis 
a. Kontribusi yang memberikan gambaran pada manajemen perusahaan tentang bagaimana pengaruh motivasi, disiplin, kepuasan kerja, dan iklim perusahaan terhadap kinerja karyawan.

b. Kontribusi yang memberikan pemahaman kepada manajemen perusahaan arti penting motivasi, disiplin, kepuasan kerja dan iklim perusahaan terhadap peningkatan kinerja karyawan. 


\section{BAB II \\ LANDASAN TEORI}

\section{A. Landasan Teori}

\section{Motivasi}

\section{a. Pengertian Motivasi}

Pada bagian ini dijelaskan secara singkat teori motivasi, disiplin, kepuasan kerja dan iklim perusahaan yang mempengaruhi kinerja karyawan. Manajemen sumber daya manusia pada umumnya terdiri dari langkah-langkah perencanaan, pelaksanaan seleksi, pengembangan, pemeliharaan, dan penggunaan sumber daya manusia untuk mencapai tujuan tertentu, baik tujuan individu maupun tujuan organisasi. Keberhasilan manajemen perusahaan sangat ditentukan oleh aktivitas-aktivitas dari kegiatan pendayagunaan sumber daya manusia, dalam hal ini perusahaan harus memiliki cara untuk meningkatkan kinerja karyawan. Kegiatan-kegiatan sumber daya manusia ini antara lain adalah dengan memotivasi karyawan, meningkatkan kedisiplinan, meningkatkan kepuasan kerja, dan memperbaiki iklim perusahaan agar karyawan dapat melakukan tugas sesuai dengan target yang diinginkan baik oleh karyawan itu sendiri ataupun oleh perusahaan.

Motivasi adalah cara untuk memuaskan dan memenuhi kebutuhan seseorang, dalam hal ini berarti kebutuhan seseorang karyawan yang perlu dipenuhi dengan faktor-faktor tertentu, orang tersebut harus dapat mengerahkan upaya terbaik untuk mencapai tujuan perusahaan (Robbins, 2013:202). Dalam teori Herzberg (1996) yang ditulis oleh Wijayanto (2012:151) bahwa motivasi dibagi menjadi dua faktor yaitu faktor motivator atau yang juga sering disebut sebagai motivasi intrinsik dan faktor 
hygiene atau yang sering disebut dengan motivasi ekstrinsik. Motivasi ekstrinsik kemudian dibagi menjadi dua dimensi, dimana masing-masing dimensi mempengaruhi aspek-aspek yang terpisah dari disiplin, kepuasan kerja dan iklim perusahaan. Hygiene factor mencegah ketidakpuasan tetapi faktor ini tidak mengarah kepada kepuasan. Mengukur dan mengetahui ketidakpuasan akan membantu manajer untuk dapat memutuskan apa yang dapat memotivasi karyawannya. Berikut ini adalah rincian dari masing-masing motivasi tersebut.

\section{1) Motivasi Intrinsik}

Motivasi intrinsik adalah motivasi yang mendorong seseorang untuk berprestasi, dan yang bersumber dari dalam diri individu itu sendiri, hal ini lebih dikenal sebagai faktor motivasional. Menurut Robbins (2012:433), hal-hal yang termasuk sebagai faktor motivasional antara lain adalah:

a) Achievement (prestasi kerja) adalah keberhasilan seorang karyawan dalam menyelesaikan tugas.

b) Advancement (pengembangan diri) adalah suatu keinginan seseorang untuk mengembangkan karier di bidang tertentu.

c) Work itself (pekerjaan itu sendiri) adalah kemampuan kontrol atas metode serta langkah-langkah kerja.

d) Recognizition (pengakuan) artinya karyawan memperoleh pengakuan dari perusahaan bahwa dia adalah orang yang berprestasi dan layak mendapatkan penghargaan serta pujian atas hasil pekerjaannya.

e) Responsibility (tanggung jawab) artinya karyawan memikul tanggung jawab atas pekerjaaan yang dilaksanakannya. 
f) Growth (pengembangan diri), kebutuhan akan pengembang diri baik secara materil maupun moril.

\section{2) Motivasi Ekstrinsik}

Motivasi ekstrinsik adalah motivasi yang bersumber dari luar diri seseorang, motivasi ini turut menentukan perilaku seseorang dan berperan dalam kehidupan seseorang yang dikenal sebagai teori hygiene factor. Menurut Herzberg (1966) dalam Hong dan Waheed (2011), hal-hal yang tergolong sebagai hygiene factor antara lain adalah sebagai berikut:

a) Company policy (kebijakan perusahaan) adalah aturan yang ditetapkan oleh perusahaan sebagai acuan manajemen dalam melaksanakan kegiatan.

b) Relationship with peers (hubungan dengan rekan kerja) adalah komunikasi antar karyawan dalam rangka menyelesaikan tugas.

c) Work security (kelangsungan kerja) adalah persepsi individu karyawan terhadap variabilitas nilai imbalan karyawan, remunerasi, ancaman mutasi, atau pemutusan hubungan kerja.

d) Relationship with supervisor (hubungan dengan atasan) merupakan unsur utama dari kepuasan kerja karyawan.

e) Gaji atau remunerasi adalah imbalan finansial yang diterima oleh karyawan meliputi upah, bonus, dan tunjangan lainnya.

Masrukhin dan Waridin (2006) dalam Walsa dan Ratnasari (2016) mengemukakan bahwa motivasi merupakan faktor psikologis yang menunjukkan minat individu terhadap pekerjaan, termasuk rasa puas dan ikut bertanggung-jawab terhadap aktivitas atau pekerjaan yang 
dilakukan. Untuk lebih meningkatkan performance dan sikap positif, sebaiknya dilakukan pendekatan yang berpusat pada faktor-faktor motivator tersebut di atas. Pekerjaan seharusnya dirancang sedemikian rupa sehingga menghasilkan derajat penghargaan yang tinggi yang sesuai kedua faktor tersebut.

Juniantara dan Riana (2015) menyatakan bahwa pentingnya reward dalam kinerja sehari-hari, tugas pekerjaan yang tidak terlalu berlebihan, terutama pada saat menentukan hasil pekerjaan yang diberikan,akan mempengaruhi tingkat kepuasan karyawan dan motivasi karyawan serta menjadi fakta bahwa kinerja karyawan akan meningkat seiring dengan meningkatnya motivasi. Oleh karena itu penting bagi perusahaan untuk mempertimbangkan kebutuhan dan perasaan tenaga kerja dan tidak mengabaikan mereka dalam rangka menjaga keharmonisan iklim perusahaan itu sendiri.

Motivasi menurut Nawawi (2008) dalam Suprihati (2014) adalah suatu kondisi yang mendorong atau menjadi sebab seseorang melakukan sesuatu perbuatan atau kegiatan yang berlangsung secara sadar. Motivasi berkaitan dengan tingkat usaha yang dilakukan oleh seseorang dalam mengejar suatu tujuan dan berkaitan erat dengan disiplin, kepuasan kerja, iklim perusahaan dan kinerjanya.

Dalam penelitian sebelumnya, Sulastri (2017) menggambarkan bahwa seorang individu puas dengan pekerjaannya secara langsung atau tidak, tergantung pada beberapa faktor motivasi yang diberikan seperti gaji, bonus, tunjangan dan keadaan lain yang memotivasi individu tersebut. Hong dan Waheed (2011) juga menunjukkan bahwa hygiene factor adalah motivator dominan terhadap 
kepuasan kerja karyawan. Implikasi utama dari studi ini adalah bahwa karyawandapat menghargai hasil yang dicapai dengan gaji yang mereka terima.

Suprihati (2014) selanjutnya menyatakan bahwa motivasi dapat muncul dari dalam individu itu sendiri atau motivasi intrinsik dan dapat pula berasal dari luar atau motivasi ekstrinsik. Adapun yang paling dikontrol oleh motivasi ekstrinsik adalah peraturan eksternal, yang merupakan keterlibatan perilaku berdasarkan tekanan dari luar atau tuntutan dalam mencapai reward yang diinginkan. Dalam penelitiannya Suprihati (2014) bertujuan untuk menguji model dimana karakteristik pekerjaan dari pekerjaan sukarela yang berhubungan positif dengan motivasi otonom, kepuasan kerja dan kinerja.

\section{b. Indikator Motivasi}

Motivasi adalah cara untuk memuaskan dan memenuhi kebutuhan seseorang dan dimensinya meliputi (1) tanggung jawab, (2) keinginan berprestasi, (3) minat atas pekerjaan, (4) hubungan kerja, (5) penghargaan. Menurut Isbahi (2013:40) dimensi ini meliputi indikator-indikator sebagai berikut:

1) Tanggung jawab: keinginan menyelesaikan pekerjaan, merawat peralatan kerja, menguasai pekerjaan dan memperolah pengakuan atas hasil kerja.

2) Keinginan berprestasi: keinginan meningkatkan pengetahuan dan ketrampilan, berkompetisi dengan rekan kerja dan bersedia bekerja melebihi waktu yang ditentukan.

3) Minat atas pekerjaan: keinginan untuk menikmati dan semangat dalam bekerja.

4) Hubungan kerja: keinginan akan hubungan kerja yang harmonis. 
5) Penghargaan: keinginan memperoleh penghasilan yang dapat memenuhi kebutuhan pokok.

\section{Disiplin}

\section{a. Pengertian Disiplin}

Disiplin atau disiplin kerja adalah kewajiban yang harus ditaati dan larangan yang tidak boleh dilanggar oleh setiap karyawan, dimana dimaksudkan agar tujuan perusahaan dapat tercapai secara efektif dan efesiensi. Apabila seorang karyawan tidak melaksanakan disiplin, maka sudah tentu tujuan perusahaan tidak akan tercapai, dan meskipun tercapai akan tetap kurang efektif.

Pengertian disiplin telah banyak dikemukakan oleh pakar manajemen. Meskipun pengertian tersebut berbeda-beda tetapi masih memiliki maksud yang sama. Hasibuan (2016:193) mendefinisikan disiplin sebagai kesadaran dan kesediaan seseorang untuk mentaati semua peraturan perusahaan atau organisasi dan norma-norma sosial yang berlaku, dimana karyawan selalu datang dan pulang tepat waktu, dan mengerjakan semua pekerjaan dengan baik.

Sutrisno (2014) dalam Supomo dan Nurhayati (2018:133) menjelaskan bahwa disiplin kerja adalahperilaku seseorang yang sesuai dengan peraturan, prosedur kerja yang ada, atau disiplin adalah sikap tingkah laku dan perbuatan yang sesuai dengan peraturan organisasi baik yang tertulis maupun yang tidak tertulis. Disiplin yang baik mencerminkan besarnya rasa tanggungjawab seseorang terhadap tugas-tugas yang diberikan kepadanya. Karena itu setiap pimpinan selalu berusaha agar para bawahannya mempunyai disiplin yang baik. Sebab hanya dengan disiplin, tujuan perusahaan akan dapat tercapai dengan lebih efektif dan efesien. 
Penjelasan lain tentang disiplin kerja yaitu menurut Simamora (2006) dalam Sukadi (2016:24), yang menyatakan bahwa disiplin adalah prosedur yang mengoreksi atau menghukum bawahan karena melanggar peraturan atau prosedur. Disiplin merupakan bentuk pengendalian diri karyawan dan pelaksanaan yang teratur dan menunjukkan tingkat kesungguhan kerja karyawan di perusahaan. Sedangkan Fathoni (2006) dalam Khasifah dan Nugraheni (2016) mengartikan disiplin sebagai kesadaran dan kesediaan seseorang untuk mentaati semua peraturan organisasi dan norma-norma sosial yang berlaku, seperti datang dan pulang bekerja tepat waktu dan mengerjakan tugas-tugas yang dibebankan kepadanya.

Disiplin pada hakekatnya juga merupakan pembatas kebebasan karyawan namun untuk tujuan-tujuan positif perusahaan.Oleh karena itu dalam usaha menegakkan disipilin kerja karyawan, perusahaan tidak dapat secara asal menerapkannya begitu saja. Dengan kata lain disiplin bukan hanya sekedar untuk disiplin saja, akan tetapi disiplin harus juga dapat menunjang tujuan yang ingin dicapai oleh perusahaan, dan oleh sebab itu maka dalam pelaksanaan disiplin tersebut perlu adanya pengawasan.

\section{b. Tujuan dan Sasaran Disiplin}

Siswanto (2003) dalam Supomo dan Nurhayati (2018:139) menjelaskan bahwa tujuan melakukan pembinaan disiplin kerja adalah untuk kelangsungan usaha perusahaan, sesuai dengan tujuan yang direncanakan perusahaan. Sedangkan pada umumnya sasaran disiplin kerja adalah menumbuhkan kesadaran disiplin bagi karyawannya secara individu, kelompok ataupun keseluruhan. Di bawah ini diuraikan bagaimana mengembangkan sikap disiplin pribadi maupun kelompok: 
1) Disiplin Diri

Disiplin diri adalah disiplin yang dikembangkan atau dikontrol oleh diri sendiri. Hal ini merupakan manifestasi atau aktualisasi dari tanggung jawab pribadi yang berarti mengakui dan menerima nilai-nilai yang ada di luar dirinya. Melalui disiplin diri seorang karyawan dapat merasa bertanggung jawab dan dapat mengatur dirinya sendiri untuk kepentingan perusahaan. Penanaman nilai-nilai disiplin dapat berkembang apabila didukung oleh situasi lingkungan kerja yang kondusif, yaitu situasi yang diwarnai perlakuan yang konsisten dari karyawan dan pimpinan. Disiplin diri sangat besar peranannya dalam mencapai tujuan perusahaan. Melalui disiplin diri seorang karyawan selain menghargai dirinya sendiri juga dapat menghargai orang lain. Misalnya jika seorang karyawan mengerjakan tugas dan wewenang tanpa pengawasan atasan, maka pada dasarnya karyawan itu telah sadar melaksanakan tanggung jawab yang telah dipikulnya, dan karyawan tersebut sudah mampu melaksanakan tugasnya. Pada dasarnya karyawan tersebut juga telah menghargai potensi dan kemampuannya. Di sisi lain, bagi rekan sejawat, dengan diterapkan disiplin diri akan memperlancar kegiatan yang bersifat kelompok, apalagi jika tugas kelompok tersebut terkait pada dimensi waktu, dimana suatu proses kerja yang dipengaruhi urutan waktu pengerjaannya. Ketidakdisiplinan dalam suatu bidang kerja akan menghambat bidang kerja lainnya.

2) Disiplin Kelompok

Kegiatan perusahaan bukanlah kegiatan yang bersifat individu, selain disiplin diri kita masih memerlukan disiplin kelompok. Dengan demikian dapat dikatakan bahwa disiplin kelompok adalah patut, taat dan tunduknya 
kelompok terhadap peraturan, perintah dan ketentuan yang berlaku serta mampu mengendalikan diri dari dorongan kepentingan dalam upaya pencapaian cita-cita dan tujuan tertentu serta memelihara stabilitas organisasional perusahaan dan menjalankan standar-standar organisasional perusahaan tersebut. Disiplin kelompok akan tercapai jika disiplin diri telah tumbuh dalam diri karyawan. Artinya kelompok akan menghasilkan pekerjaan yang optimal jika masing-masing anggota kelompok akan memberikan andil sesuai hak dan tanggung jawabnya. Selain itu disiplin kelompok juga memberikan andil bagi pengembangan disiplin diri. Misalnya, jika budaya atau iklim dalam organisasi tersebut merupakan disiplin kerja yang tinggi, maka mau tidak mau karyawan akan membiasakan dirinya mengikuti irama kerja karyawan lainnya. Karyawan dibiasakan bertindak dengan cara berdisiplin. Kebiasaan bertindak disiplin ini merupakan awal terbentuknya kesadaran. Kaitan antara disiplin diri dan disiplin kelompok seperti dua sisi dari satu mata uang, keduanya saling melengkapi dan manunjang, dan bersifat komplementer. Disiplin diri tidak dapat dikembangkan secara optimal tanpa dukungan disiplin kelompok, sebaliknya disiplin kelompok tidak dapat ditegakkan tanpa adanya dukungan disiplin pribadi.

\section{c. Tipe Disiplin}

Disiplin adalah kegiatan manajemen untuk standar-standar organisasional, Menurut Handoko (2010:208) terdapat dua tipe kegiatan pendisiplinan, yaitu disiplin preventif dan disiplin korektif. 
1) Disiplin preventif

Disiplin preventif adalah kegiatan yang dilaksanakan untuk mendorong para karyawan agar mengikuti standar dan aturan, sehingga penyelewengan-penyelewengan dapat dicegah.Sararan pokoknya adalah untuk mendorong disiplin diri diantara para karyawan.

2) Disiplin korektif

Disiplin korektif adalah kegiatan yang diambil untuk menangani pelanggaran terhadap aturan-aturan yang ada dan mencoba untuk menghindari terjadinya pelanggaran lebih lanjut.Kegiatan korektif sering berupa suatu bentuk hukuman yang disebut sebagai tindakan pendisiplinan (disciplinary action).

\section{d. Faktor-faktor yang mempengaruhi disiplin}

Untuk memelihara dan meningkatkan disiplin kerja karyawan yang baik merupakan pekerjaan yang tidak mudah, karena banyak faktor yang mempengaruhinya. Menurut Prijodarminto (2001) dalam Sukadi (2016:28), bahwa ada tiga aspek yang perlu diperhatikan untuk menegakkan disiplin kerja karyawan di perusahaan yaitu :

1) Sikap mental

2) Pemahaman yang baik mengenai sistem aturan perilaku, norma dan kriteria yang sedemikian rupa.

3) Sikap kelakuan yang secara wajar menunjukkan kesungguhan hati,untuk mentaati secaracermat dan tertib.

Selain itu, Hasibuan (2005) dalam Supomo dan Nurhayati (2018:138) menyatakan bahwa agar pencapain hasil yang optimal dalam menjalankan kegiatan suatu perusahaan, diperlukan faktorfaktor yang mempengaruhi disiplin kerja karyawan, yaitu sebagai berikut: 
a) Tujuan dan kemampuan

Tujuan dan kemampuan karyawan ikut mempengaruhi tingkat disiplin kerja karyawan tersebut. Perusahaan harus menetapkan tujuan yang akan dicapai dan tujuan itu harus jelas serta ditetapkan secara ideal dan cukup menantang bagi kemampuan karyawan.Hal ini berarti bahwa tujuan pekerjaan yang dibebankan kepada seorang karyawan harus sesuai dengan kemampuan karyawan tersebut, agar karyawan bekerja secara bersungguh-sugguh dan menerapkan disiplin dengan baik.

b) Pimpinan teladan

Teladan pimpinan sangat berperan dalam menentukan keberhasilan disiplin kerja karyawan, karena pimpinan pada umumnya dijadikan teladan dan panutan oleh bawahannya. Pimpinan perusahaan adalah pemegang kekuasaan tertinggi dalam suatu perusahaan. Dengan demikian, pimpinan berhak mengarahkan sesuai dengan apa yang diharapkan perusahaan. Agar pimpinan dapat menjadi teladan bagi karyawan, maka pimpinan harus memberikan sikap yang baik dan positif. Pimpinan harus memberi contoh yang baik, berdisiplin baik, jujur, adil, serta sesuai kata dengan perbuatan atau memiliki integritas yang tinggi. Dengan teladan pimpinan yang baik maka disiplin kerja karyawan pun akan ikut baik. Tetapi jika teladan pimpinan kurang baik atau kurang disiplin, maka bawahan pun akan kurang disiplin. Hal inilah yang mengharuskan agar pimpinan mempunyai kedisiplinan yang baik, supaya para bawahan pun dapat berdisipilin baik dalam bekerja. Jadi, disiplin dapat dimulai dari pimpinan. Untuk mewujudkan kedisiplinan yang baik, perusahaan harus memberikan balas jasa yang relatif besar kepada karyawan. Kedisiplinan 
karyawan tidak mungkin baik, apabila balas jasa yang mereka terima kurang memuaskan untuk memenuhi kebutuhannya beserta keluarganya.

c) Balas jasa

Balas jasa (berupa gaji dan kesejahteraan) ikut mempengaruhi disiplin kerja karyawan, karena balas jasa akan memberikan kepuasan dan kecintaan karyawan terhadap pekerjaannya. Jika kecintaan karyawan semakin baik terhadap pekerjaan, maka disiplin kerjanya akan semakin baik pula.

d) Keadilan

Keadilan ikut mendorong terwujudnya disiplin kerja karyawan, karena ego dan sifat manusia yang selalu merasa dirinya penting dan minta diperlakukan sama dengan manusia laainnya. Apabila keadilan yang dijadikan dasar kebijaksanaan dan pemberian balas jasa (pengakuan) ataupun hukuman, akan merangsang terciptanya kedisiplinan karyawan yang baik. Jadi keadilan harus diterapkan dengan baik di setiap perusahaan, supaya kedisiplinan karyawan perusahaan itu baik pula.

e) Waskat

Waskat dapat diartikan sebagai pengawasan melekat yang merupakan tindakan nyata dan paling efektif dalam mewujudkan disiplin kerja karyawan,karena dengan waskat ini berarti atasan harus secara aktif dan langsung mengawasi perilaku, moral, sikap, gairah kerja dan prestasi kerja bawahannya. Waskat yang efektif akan merangsang disiplin dan moral kerja karyawan, karena karyawan merasa mendapat perhatian, bimbingan, petunjuk, pengarahanpengarahan dan pengawasan dari atasannya. 
f) Sanksi hukuman

Sanksi hukuman berperan penting dalam memelihara disiplin kerja karyawan, karena dengan sanksi hukuman yang semakin berat, karyawan akan semakin takut melanggar aturan-aturan perusahaan, sikap dan perilaku indisipliner karyawan akan berkurang. Sanksi hukuman hendaknya cukup wajar untuk setiap tindakan indisipliner, bersifat mendidik dan menjadi alat motivasi karyawan untuk memelihara kedisiplinan dalam perusahaan itu.

g) Ketegasan

Ketegasan pimpinan dalam melakukan tindakan akan mempengaruhi disiplin kerja karyawan suatu perusahaan. Pimpinan harus berani dan tegas dalam menindak setiap karyawan yang melakukan tindakan indisipliner, sesuai dengan hukuman dan sanksi yang telah ditetapkan. Pimpinan yang bertindak tegas dalam menerapkan hukuman bagi karyawan yang indisipliner, akan disegani dan diakui kemimpinannya oleh bawahan. Ketegasan pimpinan menghukum dan menegur setiap karyawan yang indisipliner akan mewujudkan disiplin kerja yang baik dalam suatu perusahaan.

h) Hubungan manusia

Hubungan kemanusian yang harmonis antara sesama karyawan ikut menciptakan tingkat disiplin kerjayang baik pada suatu perusahaan. Hubungan-hubungan itu dapat bersifat vertikal maupun horisontal yang terdiri dari direct single relationship, direct group relationship dan cross realationship yang harmonis. Jadi disiplin kerja karyawan akan tercipta apabila hubungan kemanusiaan dalam perusahaan tersebut berjalan dengan baik. 
Selain faktor-faktor tersebut diatas, Simamora (2001) dalam Hariandja (2009:300), mengungkapkan beberapa faktor lain yang mempengaruhi disiplin kerja karyawan adalah:

1) Motivasi

Motivasi sangat mempengaruhi tingkat disiplin karyawan karena motivasi merupakan metode yang lazim digunakan untuk mengetahui minat karyawan dalam mencapai tujuan tertentu.Kebijakan pimpinan dalam memotivasi karyawan dapat dilakukan dengan pemberian pandangan yang baik, perhatian, penghargaandan dapat pula dengan cara memberikan hadiah kepada karyawan yang berdisiplin tinggi.

2) Lingkungan kerja

Lingkungan kerja ikut mendorong terwujudnya disiplin kerja karyawan karena lingkungan kerja merupakan sarana akselerasi bagi karyawan dalam mencapai produktivitas kerja. Pimpinan harus memperhatikan karyawannya, bagaimana lingkungan kerjanya, termasuk kenyamanan dalam pengaturan ruangan, kebebasan privasi, dan menyediakan alat-alat pekerjaan yang diperlukan.

Dari kutipan tersebut diatas dapat diambil kesimpulan bahwa menegakkan disiplin itu dapat diharapkan sebahagian besar dari ketaatan karyawan terhadap peraturan-peraturan perusahaan dan kemampuan karyawan untuk dapat membedakan hal-hal apa yang sepatutnya dilakukan dan yang tidak dilakukan.

\section{e. Indikator Disiplin}

Disiplin adalah kesadaran dan kesediaan seseorang untuk mentaati semua peraturan perusahaan dan norma-norma sosial yang berlaku dan dimensinya meliputi (1) ketepatan waktu dalam bekerja, (2) kesadaran dalam bekerja, (3) kepatuhan pada 
peraturan. Menurut Sukadi (2016:66) dimensinya meliputi indikator-indikator sebagai berikut:

1) Ketepatan waktu dalam bekerja: bekerja tepat waktu, seperti datang tepat waktu dan pulang sesuai waktunya, dan bekerja secara efisien.

2) Kesadaran dalam bekerja: tingkat kehadiran yang baik, kemampuan memenuhi tugas, bertanggung-jawab, melaksanakan tugas dengan baik, kemampuan bekerja sama.

3) Kepatuhan pada peraturan: kemauan dalam mematuhi peraturan, taat pada peraturan, dan takut pada sanksi yang dibebankan.

\section{Kepuasan Kerja}

\section{a. Pengertian Kepuasan Kerja}

Robbins (2013:74) mendefinisikan kepuasan kerja sebagai sikap umum individu terhadap pekerjaannya. Pekerjaan membutuhkan interaksi dengan rekan sekerja dan para atasan, mematuhi peraturan serta adaptasi pada iklim perusahaan, memenuhi standar kinerja yang ditentukan, dan menyesuaikan diri pada suasana kerja yang mungkin sering kali kurang ideal. Kepuasan kerja merupakan sikap umum individu terhadap pekerjaannya sehingga lebih mencerminkan sikap danperilaku karyawan. Menurut Robbins (2013:84) bahwa banyak manajer meyakini dan menjadikannya prinsip dasar bahwa karyawan yang puas dalam pekerjaannya akan lebih produktif daripada karyawan yang tidak puas. Para peneliti yang beraliran humanis berpendapat bahwa kepuasankaryawan adalah tujuan utama perusahaan. Kepuasan tidak hanya secara negatif terkait dengan absen dan pengunduran diri, namun menurut mereka, hal ini sangat membebani organisasi karena tanggung jawab yang besar 
untuk memberikan pekerjaan yang menantang dan secara intrinsik memberikan penghargaan pada karyawan.

Teori motivator hygiene yang dikembangkan oleh Herzberg (1966) dalam Hong dan Waheed (2011) adalah salah satu teori yang membahas kepuasan kerja, karena memang teori motivator hygiene ini sebenarnya berujung pada kepuasan kerja. Untuk mendatangkan kepuasan kerja, dalam dunia usaha salah satunya adalah mengacu kepada kompensasi dan sistem remunerasi yang diberikan oleh pengusaha, termasuk gaji atau imbalan, fasilitas kerja dan lain-lain.

Gathunguet al. (2013) mendefinisikan kepuasan kerja sebagai perasaan senang karyawan sebagai akibat dari persepsi bahwa pekerjaannya memenuhi atau memungkinkan terpenuhinya nilai-nilai penting bagi karyawan itu. Definisi ini merefleksikan tiga aspek penting, yaitu:

1) Kepuasan kerja adalah fungsi nilai yang dapat didefinisikan sebagai apa yang ingin diperoleh seseorang baik sadar maupun tidak sadar.

2) Beragam pekerja atau karyawan memiliki pandangan yang berbeda menyangkut nilai-nilai yang dirasa penting dan sangat berpengaruh terhadap penentuan sifat dan derajat kepuasan karyawan itu sendiri.

3) Persepsi individu dapat saja bukan merupakan refleksi yang sepenuhnya akurat terhadap realitas, dan beragam orang dapat memandang situasi yang sama secara berbeda-beda.

Mangkunegara (2005) dalam Sulasri dan Suhardi (2017) menyimpulkan bahwa kepuasan kerja adalah suatu perasaan yang menyokong diri karyawan yang berhubungan dengan pekerjaannya dan kondisi dirinya. Kepuasan kerja adalah evaluasi yang menggambarkan perasaan dan sikap karyawan baik keadaan senang atau tidak senang, puas atau tidak puas dalam 
bekerja. Kepuasan kerja adalah tingkat rasa puas karyawan dimana mereka merasa mendapat imbalan yang setimpal dari berbagai macam aspek dan situasi pekerjaan di perusahaan tempat mereka bekerja.

Hasibuan (2016:202) mencatat bahwa kepuasan kerja karyawan umumnya dipengaruhi oleh faktor-faktor berikut:

a) Balas jasa yang adil dan layak.

b) Penempatan yang tepat dan sesuai dengan keahlian.

c) Berat-ringannya pekerjaan.

d) Suasana dan lingkungan pekerjaan (iklim pekerjaan).

e) Peralatan yang menunjang dalam melaksanakan pekerjaan.

f) Sikap pimpinan dan metode kepemimpinannya.

g) Sifat pekerjaan yang monoton atau bervariasi.

\section{b. Konsekuensi Ketidakpuasan Kerja}

Ada konsekuensi ketika karyawan menyukai pekerjaan mereka dan ada konsekuensi ketika karyawan tidak menyukai pekerjaan mereka. Sebuah kerangka teoritis yang sangat bermanfaat dalam memahami konsekuensi dari ketidakpuasan. Respon-respon tersebut oleh Robbins (2013:82) didefinisikan sebagai berikut:

1) Keluar (exit): perilaku yang ditunjukkan untuk meninggalkan perusahaan, termasuk untuk mencari posisi baru, dan mengundurkan diri.

2) Aspirasi (voice): secara aktif dan variabeltif berusaha memperbaiki kondisi, termasuk menyarankan perbaikan, mendiskusikan masalah dengan atasan, dan beberapa bentuk aktivitas serikat pekerja.

3) Kesetian (loyalty): secara pasif tetapi optimis menunggu membaiknya kondisi, termasuk membela perusahaan ketika berhadapan dengan ancaman eksternal dan mempercayai 
perusahaan dan manajemennya untuk 'melakukan hal-hal yang benar'.

4) Pengabaian (neglect): secara pasif membiarkan kondisi menjadi lebih buruk, termasuk ketidakhadiran dan keterlambatan yang terus-menerus, kurang usaha, dan meningkatnya angka kesalahan.

Menurut Supomo dan Nurhayati (2018) bahwa kepuasan kerja yang tinggi akan berpengaruh secara positif terhadap kedisiplinan kerja, dan kedisiplinan kerja yang baik akan berpengaruh secara positif terhadap produktivitas kerja. Banyak penelitian sebelumnya membuktikan bahwa karyawan yang puas dengan pekerjaannya akan menjadi karyawan yang lebih produktif, sedangkan pekerja yang tidak puas akan mengambil perilaku keluar (exit) dan pengabaian (neglect) dan akan mempengaruhi variabel-variabel kinerja produktivitas lainnya seperti:

a) Terhadap produktivitas

Orang berpendapat bahwa produktivitas perusahaan dapat dinaikkan dengan meningkatkan kepuasan kerja, dan kepuasan kerja mungkin merupakan akibat dari produktivitas atau sebaliknya. Tetapi sebenarnya produktivitas yang tinggi dapat menyebabkan peningkatan kepuasan kerja apabila karyawan dapat menerima bahwa apa yang telah dicapai oleh perusahaan sudah sesuai dengan apa yang mereka terima, misalnya gaji atau upah yang adil dan wajar serta disesuaikan dengan performa kerja yang unggul. Dengan kata lain bahwa performansi kerja menunjukkan tingkat kepuasan kerja seorang karyawan, karena perusahaan dapat mengetahui aspek-aspek pekerjaan dari tingkat keberhasilan yang diharapkan. 
b) Ketidakhadiran (Absentism)

Kepuasan kerja dan ketidakhadiran dapat saja menunjukkan korelasi negatif. Sebagai contoh perusahaan memberikan cuti sakit atau cuti kerja dengan bebas tanpa sanksi, termasuk kepada pekerja yang sangat puas ataupun tidak puas. Akan tetapi ketidakhadiran selain karena cuti, sakit atau izin yang sah diberikan oleh perusahaan, maka hal ini boleh saja dipengaruhi oleh ketidakpuasan kerja.

c) Keluarnya pekerja (Turnover)

Berhenti atau keluar dari pekerjaan mempunyai akibat ekonomis yang besar, dan dampak yang besar kemungkinannya berhubungan dengan ketidakpuasan kerja.

\section{c. Indikator Kepuasan Kerja}

Kepuasan kerja adalah suatu perasaan yang menyokong diri karyawan yang berhubungan dengan pekerjaannya dan kondisi dirinya, dan dimensinya meliputi (1) kepuasan dengan gaji, (2) kepuasan dengan promosi, (3) kepuasan dengan rekan kerja, kepuasan dengan atasan, dan kepuasan dengan pekerjaan sendiri. Menurut Mariam (2009:54) dimensi ini meliputi indikatorindikator sebagai berikut:

1) Kepuasan dengan gaji: kepuasan karena memperoleh gaji yang baik dan tunjangan yang memadai.

2) Kepuasan dengan promosi: kepuasan pada sistem promosi yang digunakan dan kepuasan pada intensitas promosi.

3) Kepuasan terhadap rekan kerja: kepuasan pada dukungan dari rekan kerja dan kesenangan yang diperoleh dari bekerja dekan rekan kerja.

4) Kepuasan dengan atasan: memperoleh dukungan dari atasan dan motivasi kerja yang diberikan oleh atasan. 
5) Kepuasan dengan pekerjaan sendiri: memperoleh kesenangan pada pekerjaan sendiri dan merasa senang bertanggung-jawab terhadap pekerjaan sendiri.

\section{Iklim Perusahaan}

\section{a. Pengertian Iklim Perusahaan}

Istilah iklim organisasi atau perusahaan pertama kali dipakai oleh Kurt Lewin pada tahun 1930-an, saat itu Lewin menggunakan istilah iklim psikologi, kemudian iklim organisasi dipakai oleh R. Tagiuri dan G. Litwin. Menurut Dame (2009) dalam Bianca dan Susihono (2012), bahwa iklim organisasi atau perusahaan merupakan kualitas lingkungan internal yang secara relatif terus berlangsung dan dialami oleh setiap anggota organisasi dalam hal ini karyawan dan iklim tersebut mempengaruhi perilaku setiap karyawan. Sedangkan Litwin dan Stringer dalam Dame (2009) dalam Bianca dan Susihono (2012) menyatakan bahwa iklim organisasi sebagai "a concept describing the subjective nature or quality of the organizational environment. Its properties can be perceivedor experienced by members of organization and reported by them in an appropriate questionnaire”. Dari pengertian di atas, iklim organisasi atau selanjutnya disebut iklim perusahaan, dapat dimaknai sebagai suatu konsep yang menggambarkan kondisi subyektif atau kualitas lingkungan organisasi, yang situasinya dapat dipersepsikan atau dialami oleh setiap anggota organisasi itu dan dituangkan dalam bentuk angket yang memadai.

Iklim perusahaan didefinisikan oleh para ahli secara beragam dan penggunaannya kerap kali dipertukarkan dengan budaya perusahaan. Iklim perusahaan sering dianologikan dengan kepribadian individu dan dipandang sebagai bagian dari lingkungan perusahaan yang berkaitan dengan aspek-aspek psikologis serta direfleksikan melalui interaksi di dalam maupun 
diluar perusahaan. Davis dan Newstorm (2002) dalam Syarif (2015) menjelaskan iklim perusahaan sebagai sesuatu yang intangible atau tidak terukur, tetapi penting untuk sebuah perusahaan dan dapat mempengaruhi kepribadian individu atau karyawan perusahaan itu. Kemudian Simamora (2001) dalam Syarif (2015) juga mengatakan bahwa iklim perusahaan adalah lingkungan internal atau psikologis perusahaan yang juga merupakan konsep yang secara subyektif melukiskan kualitas lingkungan internal perusahaan itu.

Selanjutnya, Syaiful Sagala (2008) dalam Isbahi (2013:25) mengungkapkan bahwa iklim perusahaan adalah serangkaian sifat lingkungan kerja, yang dinilai langsung atau tidak langsung oleh karyawan dan dianggap menjadi kekuatan utama dalam mempengaruhi perilaku karyawan. Stringer dalam Wirawan (2007) dalam Ratnasari dan Sutjahjo (2017) mengungkapkan bahwa karakteristik atau dimensi iklim perusahaan mempengaruhi motivasi karyawan untuk berperilaku tertentu. Oleh sebab itu maka motivasi karyawan dapat dikatakan dipengaruhi oleh iklim perusahaan dimana karyawan tersebut bekerja.

Iklim perusahaan terbuka yaitu yang didasarkan pada rasa hormat, kepercayaan dan kejujuran, serta memberikan peluang kepada manajer, manajemen perusahaan dan karyawan untuk terlibat secara konstruktif dan kooperatif satu dengan yang lain. Made Pidarta (2004) dalam Isbahi (2013:25) menuliskan bahwa iklim perusahaan mencakup praktik, tradisi dan kebiasaan bekerja dalam perusahaan. Bila kebiasaan karyawan bekerja secara efektif dan efisien maka hal ini akan dapat meningkatkan produktivitas. Oleh sebab itu iklim perusahaan perlu terus dibina melalui pelatihan-pelatihan kepemimpinan dan sebagainya. Berdasarkan pendapat para ahli di atas, dapat disimpulkan bahwa 
iklim perusahaan merupakan suatu kondisi, dimana keadaan perusahaan dan lingkungannya dalam keadaan yang aman, nyaman, damai dan menyenangkan untuk bekerja.

\section{b. Faktor-faktor yang mempengaruhi Iklim Perusahaan}

Iklim perusahaan dirumuskan sebagai kondisi lingkungan kerja yang diciptakan dan dirasakan oleh para anggotanya serta mempengaruhi perilaku karyawannya. Hal ini digambarkan melalui seperangkat nilai-nilai dan karakteristik tertentu dari perusahaan itu sendiri. Davis (2001) dalam Syarif (2015) menyebutkan bahwa unsur-unsur yang menyokong terciptanya iklim perusahaan yang menyenangkan adalah:

1) Kualitas kepemimpinan,

2) Kadar kepercayaan,

3) Komunikasi, ke atas dan ke bawah,

4) Perasaan melakukan pekerjaan yang bermanfaat,

5) Tanggung jawab,

6) Imbalan yang adil,

7) Tekanan pekerjaan yang nalar,

8) Kesempatan,

9) Pengendalian,

10) Struktur dan birokrasi yang nalar,

11) Keterlibatan dan partisipasi.

Stringer (2002) dalam Syarif (2015) mengemukakan bahwa terdapat lima faktor yang mempengaruhi terjadinya sistem organisasi, yaitu lingkungan eksternal, strategi, praktik kepemimpinan, pengaturan organisasi dan sejarah perusahaan. Lebih jauh Syarif (2015) juga menyebutkan bahwa struktur organisasi, teknologi, lingkungan luar dan kebijakan serta praktik manajemen merupakan faktor yang berpengaruh penting terhadap iklim perusahaan. 


\section{c. Indikator Iklim Perusahaan}

Menurut Timpe (1993) dalam Isbahi (2013:41), terdapat enam indikator iklim perusahaan yang meliputi:

1) Kepemimpinan

Gaya kepemimpinan yang mempengaruhi iklim perusahaan, adanya komitmen atasan terhadap bawahannya dan perhatian atasan pada permasalahatan kerja.

2) Komformitas

Adanya batasan-batasan yang diberlakukan dalam perusahaan, seperti peraturan-peraturan yang tidak relevan dengan tujuan perusahaan, mengakibatkan perusahaan memiliki nilai komformitas yang tinggi.

3) Komunikasi

Kemampuan atasan memotivasi pekerja, mengatasi konflik dan hubungan kerja yang harmonis antara atasan dan bawahan.

4) Penghargaan

Iklim perusahaan yang harmonis akan mempunyai produktivitas yang maksimal. Karyawan akan mendapat penghargaan dan imbalan yang baik dari hasil kerjanya oleh perusahaan. Tidak adanya penghargaan atas hasil kerja karyawan oleh perusahaan akan mengakibatkan rendahnya iklim perusahaan.

Iklim perusahaan hanya tercipta jika semua karyawan memiliki tingkat keyakinan yang tinggi dan mempercayai keadilan akan tindakan pemimpin. Iklim perusahaan penting untuk diciptakan karena merupakan persepsi seorang tentang apa yang diberikan oleh perusahaan dan dijadikan dasar bagi penentuan tingkah laku karyawan selanjutnya. Iklim ini ditentukan oleh seberapa baik karyawan dapat diarahkan, dibangun, dan dihargai oleh perusahaannya. 


\section{Kinerja Karyawan}

\section{a. Pengertian Kinerja}

Istilah kinerja berasal dari kata Job Performance atau Work Performance, yang mengandung pengertian sebagaiprestasi kerja. Pengertian kinerja sebagaimana yang dijelaskan oleh Mangkunegara (2005) dalam Sulasri dan Suhardi (2017) adalah hasil kerja secara kualitas dan kuantitas yang dicapai oleh seseorang karyawan dalam melaksanakan tugasnya sesuai dengan tanggung jawab yang diberikan kepadanya. Selanjutnya, Simanjuntak (2011:1) mendefinisikan kinerja perusahaan sebagai tingkat pencapaian hasil dalam rangka mewujudkan tujuan perusahaan. Hal ini termasuk bagaimana karyawan melaksanakan tugas dan kewajibannya sesuai dengan wewenang dan tanggungjawab masing-masing, dalam rangka upaya mencapai tujuan perusahaan tersebut yang legal, tidak melanggar hukum dan sesuai dengan moral maupun etika masyarakatnya.

Pendapat ahli di atas memaknai kinerja sebagai hasil kerja baik secara kualitas ataupun kuantitas yang dicapai oleh sesorang atau sekolompok orang dalam melaksanakan tugas sesuai dengan tanggung-jawabnya. Kinerja mengandung pengertian sebagai suatu kemampuan yang dapat dicapai karyawan sebagai persyaratan pekerjaannya. Dengan demikian kinerja dapat dijabarkan melalui tingkat keberhasilan dalam mencapai tujuan perusahaan. Sejalan dengan pendapat Siagian (2014:166) yang mendefisikan kinerja sebagai suatu keadaan yang menunjukkan kemampuan seorang karyawan dalam menjalankan tugas sesuai dengan standar yang telah ditentukan oleh perusahaan sesuai dengan job description-nya.

Semakin berkembangnya perusahaan maka semakin banyak pula melibatkan tenaga kerja dalam usaha menunjang kelancaran jalannya operasional perusahaan, disamping memperhatikan 
faktor-faktor produksi lainnya. Jika kita berbicara mengenai produk dan jasa yang dihasilkan oleh suatu perusahaan maka hal tersebut tidak akan terlepas dari permasalahan kinerja.

Berikut ini adalah apa saja yang dikemukakan oleh para ahli tentang kinerja sebagaimana yang dituliskan oleh Wibowo (2017:2) di bawah ini:

1) Colquit et al. (2011) mengemukakan bahwa kinerja adalah nilai serangkaian perilaku karyawan yang memberikan kontribusi, baik secara positif maupun negatif, pada penyelesaian tujuan perusahaan.

2) Cascio (2013) memandang kinerja sebagai cara untuk memastikan bahwa karyawan secara individual atau kelompok (tim) tahu apa yang diharapkan dari mereka dan mereka tetap fokus pada kinerja efektif dengan memberikan perhatian pada tujuan, ukuran dan penilaian.

3) Gibson et al. (2012) berpendapat bahwa kinerja adalah hasil dari pekerjaan yang berkaitan dengan tujuan perusahaan seperti kualitas, efisiensi dan kriteria lain dari efektivitas.

Sehubungan pendapat para ahli diatas maka kinerja dapat dimaknai sebagai kemampuan seseorang yang dapat menyelesaikan pekerjaannya sesuai dengan standar output, baik dalam kuantitas ataupun kualitas. Selanjutnya Wibowo (2017:14) juga menyatakan bahwa untuk mencapai tujuan dan sasaran perusahaan, perusahaan atau pimpinan perusahaan perlu mengelola pelaksanaan kinerja dan untuk itu perlu dilakukan pengukuran kinerja atau evaluasi kinerja.

Keberhasilan suatu kinerja akan sangat tergantung dan ditentukan oleh beberapa aspek dalam melaksanakan pekerjaan, antara lain kejelasan peran (role clarity), tingkat kompetensi (competencies), keadaan lingkungan (environment), dan faktor 
lainnya, seperti nilai (value), budaya (culture), kesukaan (preference), imbalan dan pengakuan (reward and recognition).

\section{b. Faktor- faktor yang mempengaruhi kinerja}

Untuk mengetahui faktor yang mempengaruhi kinerja individu, perlu dilakukan pengkajian terhadap teori kinerja. Secara umum faktor fisik dan non-fisik sangat mempengaruhi kinerja. Berbagai kondisi lingkungan fisik sangat mempengaruhi kondisi karyawan dalam bekerja. Selain itu, kondisi lingkungan fisik juga akan mempengaruhi berfungsinya faktor lingkungan non-fisik. Pada kesempatan ini pembahasan kita fokuskan pada lingkungan non-fisik, yaitu kondisi-kondisi yang sebenarnya sangat melekat dengan sistem manajerial perusahaan.

Ratnasari dan Sutjahjo (2017) mengungkapkan bahwa kepuasan mempunyai pengaruh positif dan signifikan terhadap kinerja karyawan. Selanjutnya, Amstrong dan Baron (1998) dalam Wibowo (2017:98), mengungkapkan faktor-faktor yang mempengaruhi kinerja adalah :

1) Personal factors, ditunjukkan untuk tingkat ketrampilan, kompetensi yang dimiliki, motivasi dan komitmen individu.

2) Leadership factor, ditentukan oleh kualitas dorongan, bimbingan dan dukungan yang dilakukan oleh team leader, dalam perusahaan dapat berarti manajer atau supervisor.

3) Team factors, ditunjukkan oleh kualitas dukungan yang diberikan oleh rekan sekerja.

4) System factors, ditunjukkan oleh adanya sistem kerja dan fasilitas yang diberikan organisasi.

5) Contextual/situational factors, ditunjukkan oleh tingginya tingkat tekanan dan perubahan lingkungan internal dan eksternal, dalam hal ini adalah lingkungan internal dan external perusahaaan. 
Lebih jauh, Badeni (2013:69) menyatakan, stres dalam bekerja sangat menentukan dalam pencapaian kinerja seseorang. Stres dapat menghambat ataupun memicu pencapain kinerja. Stres kerja dapat dipengaruhi oleh lingkungan kerja, organisasi ataupun kondisi individu yang bersangkutan.

\section{c. Evaluasi Kinerja}

Menurut Simanjuntak (2011) bahwa evaluasi kinerja adalah suatu sistem dan cara penilaian pencapaian hasil kerja suatu perusahaan atau organisasi dan penilaian pencapaian hasil kerja setiap individu yang bekerja di dalam dan untuk perusahaan tersebut. Evaluasi atau pengukuran kinerja dapat dilakukan melalui dua pendekatan. Pertama, membandingkan hasil yang dicapai dengan standar atau kriteria yang harus dicapai. Kedua, membandingkan pekerjaan atau tugas yang dikerjakan dengan uraian jabatan atau tugas (job description) yang dibebankan kepada karyawan.

Pada umumnya evaluasi atau pengukuran kinerja dapat dilakukan melalui beberapa tahapan:

1) Merumuskan dan menetapkan standar ukur atau kriteria,

2) Mengumpulkan dan menyeleksi informasi (melakukan appraisal),

3) Mendeskripsikan dan menginterpretasikan data,

4) Mengembangkan dan mengkaji informasi,

5) Menarik kesimpulan.

\section{d. Indikator Kinerja Karyawan}

Kepuasan kerja adalah suatu perasaan yang menyokong diri karyawan yang berhubungan dengan pekerjaannya dan kondisi dirinya, dan dimensinya meliputi (1) perilaku inovatif, (2) pengambilan inisiatif, (3) manajemen waktu, (4) pencapaian kuantitas dan kualitas pekerjaan, (5) kemampuan diri untuk mencapai tujuan, dan (6) hubungan dengan rekan kerja dan 
pelanggan. Menurut Mariam (2009:51) dimensi-dimensi ini meliputi indikator-indikator sebagai berikut:

1) Perilaku inovatif: kemampuan bekerja ekstra melebihi waktu minimum yang ditentukan dan semangat untuk bekerja lebih keras.

2) Pengambilan inisiatif: orientasi pada pelanggan dan inisiatif bekerja mandiri.

3) Manajemen waktu: kemampuan bekerja tepat waktu dan penuh kerapihan.

4) Pencapaian kuantitas dan kualitas pekerjaan: kualitas kerja yang baik dan menyelesaikan kerja dengan baik.

5) Kemampuan diri untuk mencapai tujuan: pencapaian tujuan dan sasaran yang ditentukan serta bekerja sesuai tujuan.

6) Hubungan dengan rekan kerja dan pelanggan: kemampuan bekerja-sama dengan rekan kerja dan memahami kebutuhan pelanggan.

\section{B. Kerangka Pemikiran}

Motivasi, disiplin, kepuasan kerja dan iklim perusahaan dipercaya mempunyai pengaruh yang cukup besar terhadap kinerja karyawan. Dengan adanya motivasi dari manajemen dan kepuasan kerja yang tinggi akan menghasilkan kinerja yang baik pula. Schulze et al. (2003) dalam Hong dan Waheed (2011) menegaskan bahwa untuk memahami perilaku karyawan di tempat kerja, manajer harus menyadari konsep kebutuhan atau motif yang akan membantu karyawan mereka untuk bertindak dalam menyelesaikan pekerjaan. Hal ini terjadi bukan saja secara individu tetapi juga dari kelompok karyawan yang ada. Kreativitas, keandalan dan kualitas sumber daya manusia menjadi tumpuan dari suatu perusahaan. Dalam rangka peningkatan kualitas sumber daya manusia dibutuhkan suatu motivasi dan kepuasan kerja seseorang untuk mencapai hasil kerja atau produktivitas.

Dalam perusahaan, kinerja adalah output yang diraih seorang karyawan dalam jangka waktu tertentu. Menurut Robbins (2013:74) dan Wijayanto 
(2012:147) bahwa motivasi adalah proses yang memperhitungkan intensitas, arahan dan kegigihan dalam upaya meraih tujuan. Dalam hal ini bukan saja tujuan individu tetapi juga secara kolektif akan menjadi tujuan perusahaan. Dalam dimensi kinerja, motivasi bukan satu-satunya faktor yang mempengaruhi kinerja. Faktor-faktor lain seperti disiplin, kepuasan kerja dan iklim perusahaan dapat saja mempengaruhi kinerja perusahaan.

Kepuasan kerja merupakan hal yang bersifat pribadi sehingga akan terjadi dinamika atau perubahan-perubahan setiap waktu, namun tetap harus diantisipasi agar tidak berkembang ke arah hal-hal yang bersifat negatif yang merugikan perusahaan. Tiap-tiap individu mempunyai tingkat kepuasan yang berbeda-beda dengan nilai-nilai yang berlaku pada dirinya, semakin banyak aspek dalam pekerjaan yang sesuai dengan keinginan karyawan maka semakin tinggi tingkat kepuasan yang dirasakan, dan begitu pula sebaliknya.

Dari uraian tersebut dapat dibangun kerangka konseptual yang merupakan hubungan dari kelima variabel tersebut yaitu motivasi, disiplin, kepuasan kerja, iklim perusahaan dan kinerja karyawan sebagaimana digambarkan dalam Gambar 1 di bawah. Dimana motivasi, disiplin, kepuasan kerja dan iklim perusahaan sebagai variabel eksogen dan kinerja karyawan sebagai variabel endogen.

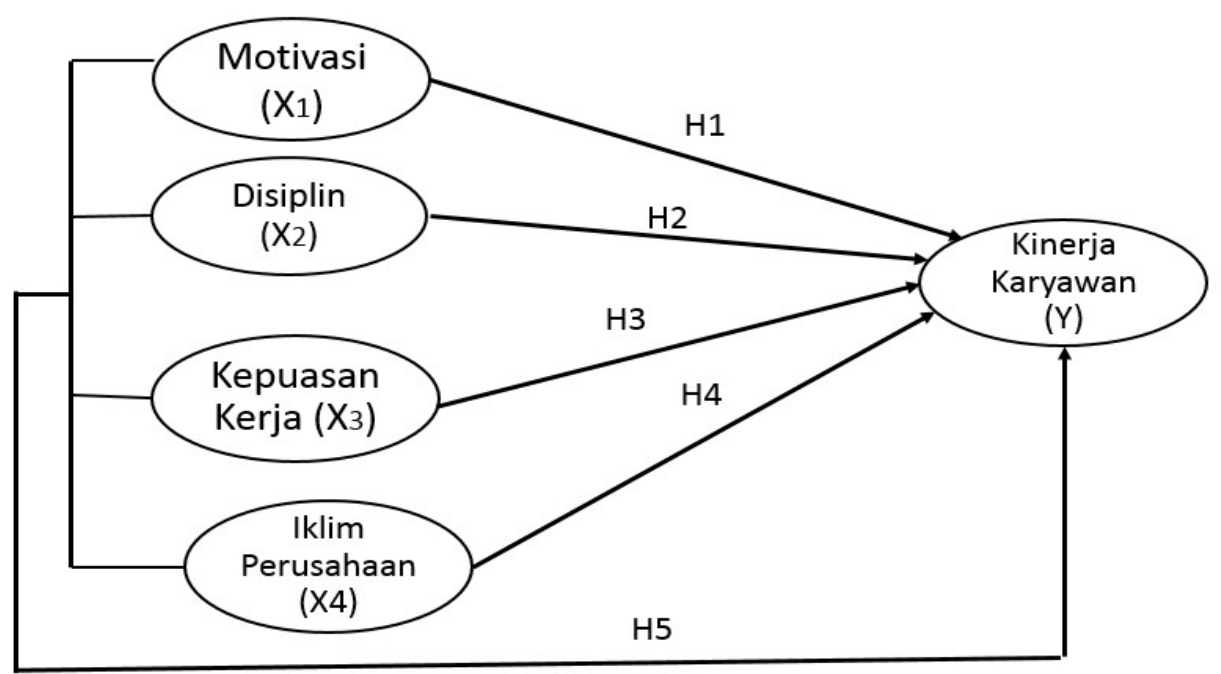

Gambar 1. Kerangka Konseptual 


\section{Hasil Penelitian Terdahulu}

Penelian Juniantara dan Riana (2015) membuktikan bahwa karyawan yang memiliki tingkat motivasi diri tinggi untuk berprestasi akan tampil lebih baik daripada mereka yang memiliki tingkat motivasi yang lebih rendah. Penelitian ini menunjukkan otoritas terkait untuk mempertimbangkan motivasi diri untuk berprestasi sebagai salah satu faktor penting dalam merekrut dan melatih karyawan.

Dalam penelitian Sulastri (2017) menunjukkan bahwa ada hubungan signifikan antara alat motivasi seperti upah, rekomendasi, pengakuan kerja dengan kinerja karyawan. Namun penelitian ini telah menunjukkan pentingnya penghargaan sebagai indikator yang layak untuk reward kinerja. Temuan Suprihati (2014) juga telah mendukung upaya penelitian ini, karena hipotesis bahwa pekerja berpenghasilan rendah akan termotivasi secara intrinsik tidak dikonfirmasi dan harapan bahwa pekerja yang berpenghasilan lebih tinggi akan menempatkan nilai yang lebih besar pada imbalan intrinsik daripada pekerja yang berpenghasilan rendah juga tidak dikonfirmasi.

Susan et al. (2012) dalam studinya menunjukkan bahwa motivasi karyawan memiliki dampak langsung pada produktivitas dan pertumbuhan. Seorang karyawan sangat termotivasi melaksanakan yang terbaik dalam setiap tugas dan tanggung jawabnya. Peningkatan kinerja karyawan akan menambah nilai organisasi itu sendiri dan produktivitas karyawan. Selain itu hasil percobaan penelitiannya menunjukkan bahwa motivasi karyawan telah memberikan penghargaan kepada karyawan dan organisasi akan menjaga kesetiaan karyawan pada level yang tinggi. Karyawan akan percaya dengan organisasi, pengawas dan manajemen puncak dan sejalan dengan itu penelitian yang dilakukan oleh Walsa dan Ratnasari (2016) menunjukkan bahwa motivasi karyawan dan kinerja organisasi berkorelasi positif pada kepercayaan karyawan terhadap organisasi atau perusahaan. Motivasi adalah alat tambahan bernilai bagi kinerja organisasi. Dalam era persaingan dan globalisasi, maka perlu membuat titik perhatian terhadap motivasi karyawan dan kepuasan kerja untuk mencapai pertumbuhan dan keberhasilan. 
Khasifah dan Nugraheni (2016) menyatakan bahwa disiplin merupakan salah satu faktor penting untuk mencapai kinerja yang baik dan juga menurut Fathoni (2006) dalam Khasifah dan Nugraheni (2016) bahwa kedisiplinan adalah kesadaran dan kesediaan seseorang untuk mentaati semua peraturan dan norma-norma sosial yang berlaku. Dalam penelitiannya Khasifah dan Nugraheni (2016) membuktikan bahwa disiplin kerja mempunyai hubungan yang positif dan signifikan terhadap kinerja karyawan.

Gathungu et al. (2013) mengungkapkan bahwa kepuasan kerjaadalah hal yang penting untuk diusahakan oleh karyawan maupun perusahaan dalam rangka meningkatkan produktivitas dan menurunkan rasio turnover karyawan. Menurut Syptak (1999) dalam Gathungu et al. (2013) bahwa kepuasan kerja adalam unsur penting dalam kondisi kerja dan mempunyai keterkaitan dengan peningkatan kinerja dan juga peningkatan komimen perusahaan. Dalam penelitiannya tersebut Gathungu et al. (2013) menyimpulkan bahwa $66.3 \%$ respondennya percaya bahwa kepuasan kerja memang mempengaruhi kinerja karyawan.

Ratnasari dan Sutjahjo (2017) dalam penelitiannyamengungkapkan bahwa iklim organisasi (work environment) secara tidak langsung mempengaruhi kinerja karyawan dan hal ini sejalan dengan apa yang diungkapkan oleh Robbins (2013: 516), bahwa karyawan akan bekerja secara maksimal apabila iklim organisasi atau perusahaan memberikan suasana lingkungan kerja yang nyaman dan mendukung karena karyawan puas dengan iklim kerja yang ada. Selanjutnya Ratnasari dan Sutjahjo (2017) mengungkapkan bahwa karyawan yang merasa puas, akan memiliki komitmen yang kuat dan tidak akan mau untuk meninggalkan pekerjaannya dan berusaha mempertahannya.

Mangkunegara (2005) dalam Sulastri dan Suhardi (2017) menyimpulkan bahwa kepuasan kerja adalah suatu perasaaan yang menyokong diri karyawan yang berhubungan dengan pekerjaannya dan kondisi dirinya. Karyawan akan merasa puas apabila aspek-aspek pekerjaan, seperti upah, 
kesempatan mengembangkan karir, mutu pengawasan, dan aspek-aspek dirinya, seperti umur, kondisi kesehatan, pendidikan, dapat diperhatikan oleh perusahaan sehingga menyokong karyawan tersebut untuk merasa puas dengan pekerjaannya. Berdasarkan hasil penelitian Sulastri dan Suhardi (2017) disimpulkan bahwa kepuasan kerja berpengaruh signifikan dan positif terhadap kinerja karyawan.

Penelitian-penelitian sebelumnya tersebut kemudian dibuatkan tabulasi beserta hasil-hasilnya yaitu sebagai berikut: (lihat Tabel 7).

\section{Tabel 7. Daftar Penelitian-Penelitian Terdahulu}

\begin{tabular}{|c|c|c|c|c|c|c|}
\hline No & $\begin{array}{l}\text { Nama } \\
\text { Penulis }\end{array}$ & Tahun & $\begin{array}{c}\text { Jenis } \\
\text { Tulisan }\end{array}$ & Variabel Bebas & $\begin{array}{l}\text { Variabel } \\
\text { Terikat }\end{array}$ & Hasil Penelitian \\
\hline 1 & Mariam & 2009 & Tesis & $\begin{array}{c}\text { Gaya } \\
\text { Kepemimpinan, } \\
\text { Budaya Organisasi } \\
\text { dan Kepuasan } \\
\text { Kerja }\end{array}$ & Kinerja & $\begin{array}{l}\text { Berpengaruh } \\
\text { secara } \\
\text { signifikan }\end{array}$ \\
\hline 2 & $\begin{array}{l}\text { Susan et. } \\
\text { al. }\end{array}$ & 2012 & Jurnal & Motivasi & Kinerja & $\begin{array}{l}\text { Berpengaruh } \\
\text { secara } \\
\text { signifikan }\end{array}$ \\
\hline 3 & $\begin{array}{l}\text { Gathungu } \\
\text { et. al. }\end{array}$ & 2013 & Jurnal & Kepuasan Kerja & Kinerja & $\begin{array}{l}\text { Berpengaruh } \\
\text { secara } \\
\text { signifikan }\end{array}$ \\
\hline 4 & Suprihati & 2014 & Jurnal & $\begin{array}{c}\text { Pendidikan, } \\
\text { Pelatihan, } \\
\text { Motivasi, Insentif } \\
\text { dan Lingkungan } \\
\text { Kerja }\end{array}$ & Kinerja & $\begin{array}{l}\text { Berpengaruh } \\
\text { secara } \\
\text { signifikan }\end{array}$ \\
\hline 5 & $\begin{array}{l}\text { Juniantara } \\
\text { dan Riana }\end{array}$ & 2015 & Jurnal & $\begin{array}{c}\text { Motivasi dan } \\
\text { Kepuasan Kerja }\end{array}$ & Kinerja & $\begin{array}{l}\text { Berpengaruh } \\
\text { secara } \\
\text { signifikan }\end{array}$ \\
\hline 6 & $\begin{array}{l}\text { Khasifah } \\
\text { dan } \\
\text { Nugraheni }\end{array}$ & 2016 & Jurnal & $\begin{array}{l}\text { Disiplin, Beban } \\
\text { Kerja dan } \\
\text { Lingkungan Kerja }\end{array}$ & Kinerja & $\begin{array}{l}\text { Berpengaruh } \\
\text { secara } \\
\text { signifikan }\end{array}$ \\
\hline 7 & Sukadi & 2016 & Tesis & $\begin{array}{l}\text { Motivasi dan } \\
\text { Disiplin }\end{array}$ & Kinerja & $\begin{array}{l}\text { Berpengaruh } \\
\text { secara } \\
\text { signifikan }\end{array}$ \\
\hline 8 & $\begin{array}{l}\text { Walsa dan } \\
\text { Ratnasari }\end{array}$ & 2016 & Jurnal & $\begin{array}{c}\text { Gaya } \\
\text { Kepemimpinan } \\
\text { dan Motivasi }\end{array}$ & Kinerja & $\begin{array}{l}\text { Berpengaruh } \\
\text { secara } \\
\text { signifikan }\end{array}$ \\
\hline 9 & $\begin{array}{l}\text { Ratnasari } \\
\text { dan } \\
\text { Sutjahjo }\end{array}$ & 2017 & Jurnal & $\begin{array}{c}\text { Kompensasi, Iklim } \\
\text { Organisasi dan } \\
\text { Kepuasan Kerja }\end{array}$ & Kinerja & $\begin{array}{l}\text { Berpengaruh } \\
\text { secara } \\
\text { signifikan }\end{array}$ \\
\hline 10 & $\begin{array}{l}\text { Sulastri } \\
\text { dan } \\
\text { Suhardi }\end{array}$ & 2017 & Jurnal & $\begin{array}{l}\text { Kepemimpinan, } \\
\text { Motivasi dan } \\
\text { Kepuasan Kerja }\end{array}$ & Kinerja & $\begin{array}{l}\text { Berpengaruh } \\
\text { secara } \\
\text { signifikan }\end{array}$ \\
\hline
\end{tabular}

Sumber: Data Olahan, 2019. 
D. Hipotesis

Berdasarkan teori dan temuan-temuan tersebut di atas (Tabel 7), maka dibuatlah hipotesis penelitian ini sebagai berikut:

H1: Diduga terdapat pengaruh motivasi terhadap kinerja karyawan pada PT. Profab Indonesia.

H2: Diduga terdapat pengaruh disiplin terhadap kinerja karyawan pada PT. Profab Indonesia.

H3: Diduga terdapat pengaruh kepuasan kerja terhadap kinerja karyawan pada PT. Profab Indonesia.

H4: Diduga terdapat pengaruh iklim perusahaan terhadap kinerja karyawan pada PT. Profab Indonesia.

H5: Diduga terdapat pengaruh motivasi, disiplin, kepuasan kerja dan iklim perusahaan secara bersama-sama terhadap kinerja karyawan pada PT. Profab Indonesia. 


\section{BAB III \\ METODE PENELITIAN}

\section{A. Jenis dan Desain Penelitian}

\section{Jenis Penelitian}

Jenis dari penelitian ini adalah penelitian kuantitatif yaitu penelitian yang difokuskan pada kajian fenomena objektif untuk dikaji secara kuantitatif (Musfiqon, 2012:59). Pengumpulan data penelitian ini dilakukan dengan menggunakan kuesioner, kemudian data dianalisis secara kuantitatif. Jenis penelitian ini adalah penelitian expost facto, yaitu penelitian yang bertujuan untuk menyelidiki peristiwa yang telah terjadi dan kemudian merunut ke belakang untuk mengetahui faktor-faktor yang menyebabkan terjadinya peristiwa tersebut (Sugiyono, 2012:7). Pada penelitian ini pengumpulan dan analisis data yang diperoleh untuk mengungkap peristiwa yang telah terjadi.

\section{Desain Penelitian}

Desain penelitian ini adalah deskriptif asosiatif dengan menggunakan teknik analisis jalur, yaitu penelitian untuk mengetahui pengaruh atau hubungan antara dua variabel atau lebih dengan mengukur koefisien atau signifikansi dengan statistik (Musfiqon, 2012:63). Pada penelitian ini data yang diperoleh dideskripsikan kemudian diuji secara statistik untuk menarik kesimpulan. Sesuai dengan permasalahan dalam penelitian yaitu pertanyaan penelitian yang bersifat menghubungkan dua variabel atau lebih yaitu variabel motivasi $\left(\mathrm{X}_{1}\right)$, disiplin $\left(\mathrm{X}_{2}\right)$, kepuasan kerja $\left(\mathrm{X}_{3}\right)$, iklim perusahaan $\left(\mathrm{X}_{4}\right)$ dan kinerja karyawan $(\mathrm{Y})$.

Rancangan penelitian ini juga disebut sebagai penelitian korelasional, yaitu penelitian yang dilakukan dengan maksud menganalisis hubungan antar variabel. Variabel-variabel yang 
digunakan adalah motivasi, disiplin, kepuasan kerja, iklim perusahaan dan kinerja karyawan, dan masing-masing akan diuraikan dalam indikator yang sesuai dan selanjutnya diturunkan menjadi butir-butir pertanyaan dalam instrumen kuesioner. Data yang dikumpulkan kemudian dilanjutkan dengan uji validitas dan reliabilitas. Untuk mendukung penelitian ini maka dibuatlah kerangka operasional penelitian seperti Gambar 2 di bawah.

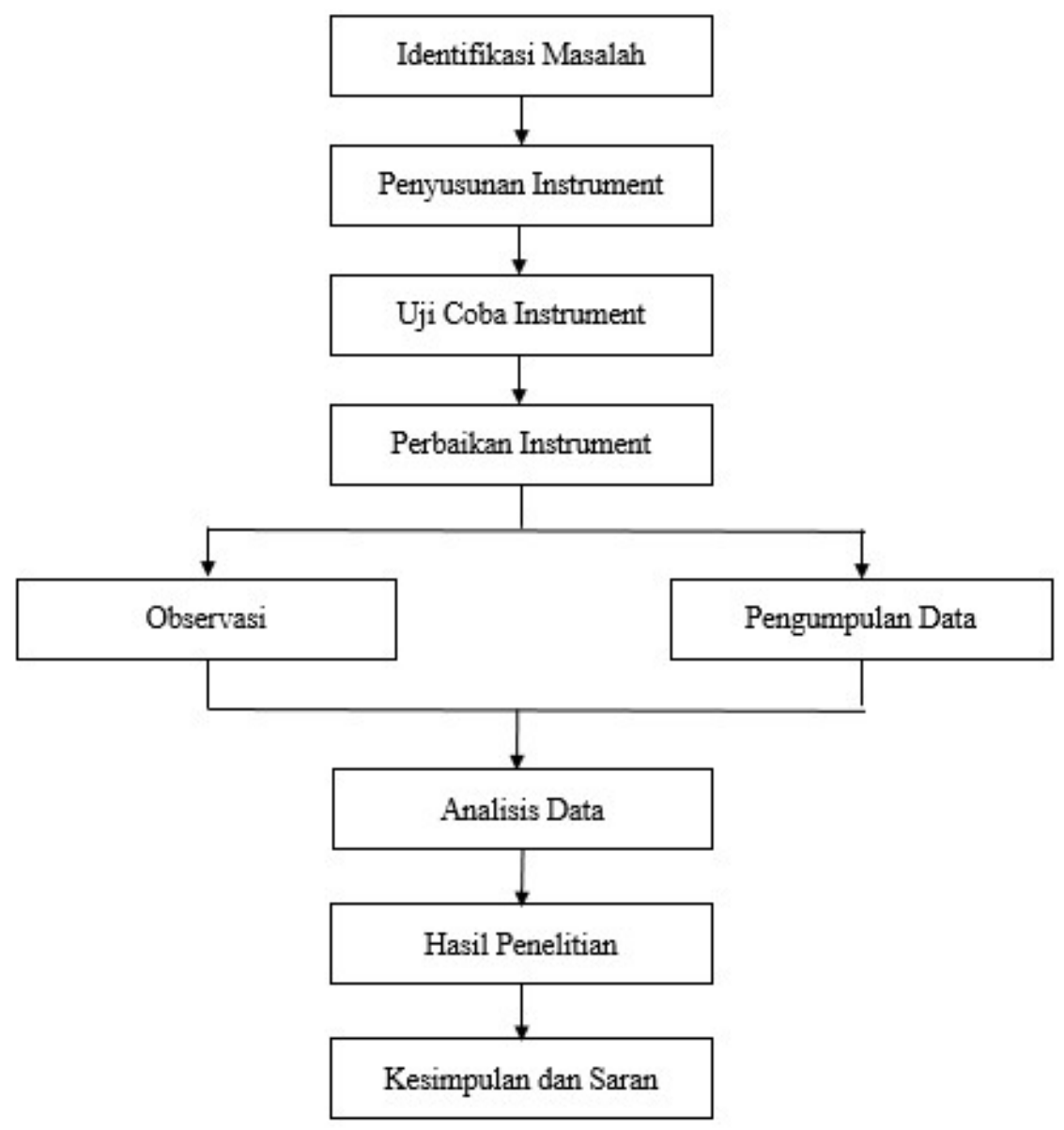

Gambar 2. Kerangka Operasional

\section{B. Populasi dan Sampel Penelitian}

\section{Populasi}

Populasi adalah sejumlah kasus atau sekelompok individu yang diteliti, yang mempunyai kualitas dan karakteristik tertentu yang diterapkan oleh peneliti untuk dipelajari dan kemudian ditarik 
kesimpulan (Dantes, 2012:37). Sementara Nazir (2014) menerangkan bahwa suatu populasi dengan jumlah individu tertentu dinamakan variabel. Keterangan mengenai populasi dapat dikumpulkan dengan dua cara. Pertama, tiap unit populasi dihitung. Cara ini disebut sensus atau complete enumeration. Kedua, perhitungan-perhitungan dilakukan hanya pada bagian unit populasi saja. Keterangan diambil dari 'wakil' populasi atau disebut juga 'sampel'. Populasi dalam penelitian ini adalah seluruh karyawan PT. Profab Indonesia, yang berjumlah 400 orang, namun oleh karena jumlah ini terlalu banyak untuk diambil semua sebagai bahan penelitian, maka penulis menggunakan metode sampling.

\section{Sampel}

Sehubungan populasi dalam penelitian ini cukup besar yaitu jumlah karyawan perusahaan sebanyak 400 karyawan, maka peneliti tidak mengambil data seluruh populasi, tetapi mengambil sampel dan dengan menggunakan rumus sampel Slovin (lihat di bawah) maka jumlah sampel yang diambil sebanyak 200 karyawan PT. Profab Indonesia, yang datanya akan diambil secara acak dari berbagai departemen di perusahaan. Departemen-departemen yang karyawannya diambil sebagai sampel adalah departemen-departemen: Supervision, Production, Quality, Engineering, Health and Safety, dsb, (lihat tabel 4.1). Kemudian jumlah angket dibagikan secara proporsional kepada masing-masing karyawan pada departemendepartemen tersebut.

Penentuan sampel dengan menggunakan rumus Slovin (Siregar, 2013:34), sebagai berikut:

$n=\frac{N}{1+N(e)^{2}}$

Keterangan:

$\mathrm{n}=$ ukuran sampel

$\mathrm{N}=$ ukuran populasi 
$\mathrm{e}=$ batas toleransi kesalahan 5\% atau 0,05 (atau tingkat akurasi 95\%).

$n=\frac{400}{1+(400)(0,05)^{2}}$

$n=\frac{400}{1+(400)(0.0025)}$

$n=\frac{400}{1+1}$

$n=\frac{400}{2}=200$

Kesimpulannya adalah bahwa jumlah angket atau kuesioner yang harus dipenuhi sebagai data penelitian adalah berjumlah minimal 200 angket (kuesioner). Jumlah sampel kemudian diambil secara proporsional dari masing-masing departemen (lihat Tabel 8).

\section{Variabel Penelitian}

\section{Identifikasi Variabel}

Penelitian ini menguji hubungan antara dua variabel yang terdiri dari:

a. Variabel eksogen atau variabel bebas adalah variabel yang mempengaruhi variabel lain, dan dalam penelitian ini terdapat empat variabel eksogen yaitu disiplin, motivasi, kepuasan kerja dan iklim perusahaan.

b. Variabel endogen atau variabel terikat adalah variabel yang dipengaruhi oleh variabel lain, dan dalam penelitian ini sebagai variabel endogen adalah kinerja karyawan. 
Tabel 8. Jumlah Pembagian Sampel

\begin{tabular}{|c|c|c|c|}
\hline No & Departemen & Jumlah Karyawan & Jumlah Sampel \\
\hline 1 & Supervisors & 10 & 5 \\
\hline 2 & Production & 300 & 150 \\
\hline 3 & Quality & 20 & 10 \\
\hline 4 & Engineering & 20 & 10 \\
\hline 5 & $\begin{array}{l}\text { Health and } \\
\text { Safety }\end{array}$ & 20 & 10 \\
\hline 6 & Maintenance & 10 & 5 \\
\hline 7 & $\begin{array}{l}G A \\
\text { Administration }\end{array}$ & 10 & 5 \\
\hline 8 & Finance & 10 & 5 \\
\hline & Total & 400 & 200 \\
\hline
\end{tabular}

Sumber: Data Olahan, 2019.

\section{Definisi Operasional}

Sebagai definisi operasional variabel dan indikator untuk masingmasing variabel di atas maka pada tabel berikut ini dirincikan tentang dimensi, indikator dan skala dari masing-masing variabel. Lihat tabeltabel di bawah ini, 
Tabel 9. Definisi Operasional Variabel Motivasi

\begin{tabular}{|c|c|c|c|}
\hline Dimensi & Indikator & $\begin{array}{c}\text { Nomor } \\
\text { Pertanyaan }\end{array}$ & Skala \\
\hline $\begin{array}{l}\text { 1. Tanggung } \\
\text { Jawab. }\end{array}$ & $\begin{array}{l}\text { 1. Menyelesaikan } \\
\text { pekerjaan } \\
\text { 2. Merawat peralatan } \\
\text { kerja. } \\
\text { 3. Keinginan untuk } \\
\text { kekuasaan. } \\
\text { 4. Keinginan akan } \\
\text { pengakuan. }\end{array}$ & $\begin{array}{l}1 \\
2 \\
3 \\
4\end{array}$ & $\begin{array}{l}\text { Likert } \\
(1-5)\end{array}$ \\
\hline $\begin{array}{l}\text { 2. Keinginan } \\
\text { Berprestasi. }\end{array}$ & $\begin{array}{l}\text { 1. Meningkatkan } \\
\text { pengetahuan dan } \\
\text { ketrampilan } \\
\text { 2. Berkompetisi dengan } \\
\text { rekan kerja } \\
\text { 3. Bersedia bekerja } \\
\text { melebihi waktu yang } \\
\text { ditentukan }\end{array}$ & $\begin{array}{l}5 \\
6 \\
7\end{array}$ & $\begin{array}{r}\text { Likert } \\
(1-5)\end{array}$ \\
\hline $\begin{array}{l}\text { 3. Minat atas } \\
\text { pekerjaan }\end{array}$ & $\begin{array}{l}\text { Menikmati dan } \\
\text { semangat dalam } \\
\text { bekerja }\end{array}$ & 8 & $\begin{array}{l}\text { Likert } \\
(1-5)\end{array}$ \\
\hline $\begin{array}{l}\text { 4. Hubungan } \\
\text { kerja }\end{array}$ & $\begin{array}{l}\text { Adanya hubungan } \\
\text { yang harmonis dalam } \\
\text { bekerja }\end{array}$ & 9 & $\begin{array}{r}\text { Likert } \\
(1-5)\end{array}$ \\
\hline 5. Penghargaan & $\begin{array}{l}\text { Penghasilan dapat } \\
\text { memenuhi kebutuhan } \\
\text { pokok }\end{array}$ & 10 & $\begin{array}{r}\text { Likert } \\
(1-5)\end{array}$ \\
\hline
\end{tabular}

Sumber: Data olahan, 2019. 
Tabel 10. Definisi Operasional Variabel Disiplin

\begin{tabular}{|c|c|c|c|}
\hline Dimensi & Indikator & $\begin{array}{c}\text { Nomor } \\
\text { Pertanyaan }\end{array}$ & Skala \\
\hline $\begin{array}{l}\text { 1. Ketepatan } \\
\text { waktu }\end{array}$ & $\begin{array}{l}\text { 1. Bekerja tepat waktu } \\
\text { 2. Bekerja efisien }\end{array}$ & $\begin{array}{l}1 \\
2\end{array}$ & $\begin{array}{l}\text { Likert } \\
(1-5)\end{array}$ \\
\hline $\begin{array}{l}\text { 2. Kesadaran } \\
\text { dalam bekerja }\end{array}$ & $\begin{array}{l}\text { 3. Tingkat kehadiran } \\
\text { yang baik } \\
\text { 4. Kemampuan } \\
\text { memahami tugas } \\
\text { 5. Bertanggung jawab } \\
\text { 6. Melaksanakan tugas } \\
\text { dengan baik } \\
\text { 7. Kemampuan bekerja } \\
\text { sama }\end{array}$ & $\begin{array}{l}6 \\
7\end{array}$ & $\begin{array}{r}\text { Likert } \\
(1-5)\end{array}$ \\
\hline $\begin{array}{l}\text { 3. Kepatuhan } \\
\text { pada } \\
\text { peraturan }\end{array}$ & $\begin{array}{l}\text { 8. Memahami } \\
\text { peraturan } \\
\text { 9. Taat pada peraturan } \\
\text { 10. Takut pada sanksi } \\
\text { yang dibebankan }\end{array}$ & $\begin{array}{c}8 \\
9 \\
10\end{array}$ & $\begin{array}{l}\text { Likert } \\
(1-5)\end{array}$ \\
\hline
\end{tabular}

Sumber: Data olahan, 2019. 
Tabel 11. Definisi Operasional Variabel Kepuasan Kerja

\begin{tabular}{|c|c|c|c|}
\hline Dimensi & Indikator & $\begin{array}{c}\text { Nomor } \\
\text { Pertanyaan }\end{array}$ & Skala \\
\hline $\begin{array}{l}\text { 1. Kepuasan } \\
\text { dengan gaji }\end{array}$ & $\begin{array}{l}\text { 1. Gaji yang lebih } \\
\text { baik } \\
\text { 2. Tunjangan yang } \\
\text { memadai }\end{array}$ & $\begin{array}{l}1 \\
2\end{array}$ & $\begin{array}{l}\text { Likert } \\
(1-5)\end{array}$ \\
\hline $\begin{array}{l}\text { 2. Kepuasan } \\
\text { dengan } \\
\text { promosi }\end{array}$ & $\begin{array}{l}\text { 1. Sistem Promosi } \\
\text { yang digunakan } \\
\text { 2. Intesitas Promosi }\end{array}$ & $\begin{array}{l}3 \\
4\end{array}$ & $\begin{array}{l}\text { Likert } \\
(1-5)\end{array}$ \\
\hline $\begin{array}{l}\text { 3. Kepuasan } \\
\text { dengan rekan } \\
\text { kerja }\end{array}$ & $\begin{array}{l}\text { 1. Dukungan dari } \\
\text { rekan kerja } \\
\text { 2. Senang bekerja } \\
\text { dengan rekan } \\
\text { kerja }\end{array}$ & $\begin{array}{l}5 \\
6\end{array}$ & $\begin{array}{l}\text { Likert } \\
(1-5)\end{array}$ \\
\hline $\begin{array}{l}\text { 4. Kepuasan } \\
\text { dengan atasan }\end{array}$ & $\begin{array}{l}\text { 1. Dukungan dari } \\
\text { atasan } \\
\text { 2. Motivasi kerja } \\
\text { atasan }\end{array}$ & $\begin{array}{l}7 \\
8\end{array}$ & $\begin{array}{l}\text { Likert } \\
(1-5)\end{array}$ \\
\hline $\begin{array}{l}\text { 5. Kepuasan } \\
\text { dengan } \\
\text { pekerjaan } \\
\text { sendiri }\end{array}$ & $\begin{array}{l}\text { 1. Senang dan } \\
\text { tertarik pada } \\
\text { pekerjaan sendiri } \\
\text { 2. Senang } \\
\text { bertanggung } \\
\text { jawab terhadap } \\
\text { pekerjaan }\end{array}$ & $\begin{array}{l}9 \\
10\end{array}$ & $\begin{array}{l}\text { Likert } \\
(1-5)\end{array}$ \\
\hline
\end{tabular}

Sumber: Data olahan, 2019. 
Tabel 12. Definisi Operasional Variabel Iklim Perusahaan

\begin{tabular}{|c|c|c|c|}
\hline Dimensi & Indikator & $\begin{array}{c}\text { Nomor } \\
\text { Pertanyaan }\end{array}$ & Skala \\
\hline $\begin{array}{l}\text { 1. Kepemimpin } \\
\text { an }\end{array}$ & $\begin{array}{l}\text { 1. Gaya } \\
\text { Kepemimpinan } \\
\text { atasan } \\
\text { 2. Komitmen atasan } \\
\text { 3. Perhatian atasan } \\
\text { pada permasalahan } \\
\text { kerja }\end{array}$ & $\begin{array}{l}1 \\
2 \\
3\end{array}$ & $\begin{array}{l}\text { Likert } \\
(1-5)\end{array}$ \\
\hline 2. Komunikasi & $\begin{array}{l}\text { 1. Kemampuan } \\
\text { atasan memotivasi } \\
\text { pekerja } \\
\text { 2. Kemampuan } \\
\text { atasan mengatasi } \\
\text { konflik } \\
\text { 3. Komunikasi } \\
\text { atasan dan } \\
\text { bawahan }\end{array}$ & $\begin{array}{l}4 \\
5 \\
6\end{array}$ & $\begin{array}{l}\text { Likert } \\
(1-5)\end{array}$ \\
\hline 3. Konformitas & $\begin{array}{l}\text { 1. Konformitas } \\
\text { terarah } \\
\text { 2. Konformitas } \\
\text { identifikasi }\end{array}$ & $\begin{array}{l}7 \\
8\end{array}$ & $\begin{array}{l}\text { Likert } \\
(1-5)\end{array}$ \\
\hline 4. Penghargaan & $\begin{array}{l}\text { 1. Penghargaan } \\
\text { kepada karyawan } \\
\text { yang berprestasi } \\
\text { 2. Prestasi kerja tim }\end{array}$ & $\begin{array}{l}9 \\
10\end{array}$ & $\begin{array}{l}\text { Likert } \\
(1-5)\end{array}$ \\
\hline
\end{tabular}

Sumber: Data olahan, 2019. 
Tabel 13. Definisi Operasional Variabel Kinerja Karyawan

\begin{tabular}{|c|c|c|c|}
\hline Dimensi & Indikator & $\begin{array}{c}\text { Nomor } \\
\text { Pertanyaan }\end{array}$ & Skala \\
\hline $\begin{array}{l}\text { 1. Perilaku } \\
\text { Inovatif }\end{array}$ & $\begin{array}{l}\text { 1. Bekerja ekstra } \\
\text { melebihi waktu } \\
\text { minimum yang } \\
\text { ditetapkan } \\
\text { 2. Semangat untuk } \\
\text { bekerja lebih keras }\end{array}$ & 2 & $\begin{array}{l}\text { Likert } \\
(1-5)\end{array}$ \\
\hline $\begin{array}{l}\text { 2. Pengambilan } \\
\text { Inisiatif }\end{array}$ & $\begin{array}{l}\text { 1. Orientasi pada } \\
\text { pelanggan } \\
\text { 2. Inisiatif bekerja } \\
\text { mandiri }\end{array}$ & $\begin{array}{l}3 \\
4\end{array}$ & $\begin{array}{l}\text { Likert } \\
(1-5)\end{array}$ \\
\hline $\begin{array}{l}\text { 3. Manajemen } \\
\text { waktu }\end{array}$ & $\begin{array}{l}\text { 1. Bekerja tepat waktu } \\
\text { 2. Bekerja dengan } \\
\text { penuh kerapihan }\end{array}$ & $\begin{array}{l}5 \\
6\end{array}$ & $\begin{array}{l}\text { Likert } \\
(1-5)\end{array}$ \\
\hline $\begin{array}{l}\text { 4. Pencapaian } \\
\text { kuantitas dan } \\
\text { kualitas } \\
\text { pekerjaan }\end{array}$ & $\begin{array}{l}\text { 1. Kualitas kerja yang } \\
\text { baik } \\
\text { 2. Menyelesaikan kerja } \\
\text { dengan baik }\end{array}$ & $\begin{array}{l}7 \\
8\end{array}$ & $\begin{array}{l}\text { Likert } \\
(1-5)\end{array}$ \\
\hline $\begin{array}{l}\text { 5. Kemampuan } \\
\text { diri untuk } \\
\text { mencapai } \\
\text { tujuan }\end{array}$ & $\begin{array}{l}\text { 1. Pencapaian tujuan } \\
\text { dan sasaran yang } \\
\text { ditentukan } \\
\text { 2. Bekerja sesuai } \\
\text { tujuan }\end{array}$ & $\begin{array}{l}9 \\
10\end{array}$ & $\begin{array}{l}\text { Likert } \\
(1-5)\end{array}$ \\
\hline $\begin{array}{l}\text { 6. Hubungan } \\
\text { dengan rekan } \\
\text { kerja dan } \\
\text { Pelanggan }\end{array}$ & $\begin{array}{l}\text { 1. Kemampuan bekerja } \\
\text { sama dengan rekan } \\
\text { kerja } \\
\text { 2. Memahami } \\
\text { kebutuhan } \\
\text { pelanggan }\end{array}$ & $\begin{array}{l}11 \\
12\end{array}$ & $\begin{array}{l}\text { Likert } \\
(1-5)\end{array}$ \\
\hline
\end{tabular}

Sumber: Data olahan, 2019. 


\section{Instrumen Penelitian}

Menurut Nazir (2014:153) pengumpulan data adalah suatu proses pengadaan data primer untuk keperluan penelitian. Pengumpulan data merupakan langkah yang amat penting dalam penelitian ilmiah. Sementara Siregar (2013:17) mengemukakan bahwa pengumpulan data adalah suatu prosedur sistematis dan standar untuk memperoleh data yang diperlukan. Dalam penelitian ini penulis menggunakan beberapa teknik pengumpulan data seperti observasi, penggunaan angket, dokumentasi dan wawancara, sehingga dapat diperoleh data yang mewakili populasi yang diteliti. Adapun teknik pengumpulan data yang dilakukan meliputi observasi, angket (kuesioner), dokumentasi, dan wawancara.

Teknik pengumpulan data variabel motivasi, disiplin, kepuasan kerja, iklim perusahaan dan kinerja karyawan dalam penelitian ini akan dijaring dengan menggunakan angket. Angket adalah sejumlah pertanyaan tertulis yang digunakan untuk memperoleh informasi dari responden dalam arti laporan tentang pribadinya atau hal-hal lain yang perlu diketahui (Arikunto, 2009:90). Penyusunan angket-angket dalam penelitian ini bertitik-tolak pada variabel penelitian dan isi dari rumusan hipotesis penelitian atau rumusan masalah yang dikembangkan ke dalam item-item pertanyaan.

Cara pengukuran variabel yang digunakan dalam penelitian adalah dengan menggunakan instrumen berupa angket. Angket yang digunakan berupa angket tertutup, yang bertujuan untuk memperoleh gambaran secara umum mengenai variabel motivasi, disiplin, kepuasan kerja, iklim perusahaan dan kinerja karyawan. Angket untuk mengukur variabel menggunakan skala Likert.Variabel Kinerja karyawan (Y), disusun dengan skala dan skor, yaitu; Sangat Baik=5, Baik=4, Kurang Baik=3, Tidak Baik=2, dan Sangat Tidak Baik=1.Variabel Motivasi $\left(\mathrm{X}_{1}\right)$, disusun dengan skala dan skor, yaitu; Sangat Baik=5, Baik=4, Kurang Baik=3, Tidak Baik=2, dan Sangat Tidak Baik=1. Variabel Disiplin $\left(\mathrm{X}_{2}\right)$, disusun dengan skala dan skor, yaitu; Sangat Baik=5,Baik=4, Kurang Baik=3, Tidak Baik=2, Sangat Tidak Baik=1. Variabel Kepuasan kerja $\left(\mathrm{X}_{3}\right)$, disusun 
dengan skala dan skor, yaitu; Sangat Baik=5, Baik=4, Kurang Baik=3, Tidak Baik=2, Sangat Tidak Baik=1,dan variabel Iklim perusahaan $\left(\mathrm{X}_{4}\right)$, disusun dengan skala dan skor, yaitu; Sangat Baik=5, Baik=4, Kurang Baik=3, Tidak Baik=2, Sangat Tidak Baik=1.

Bahan penelitian merupakan instrumen angket yang dibagikan kepada karyawan sejumlah yang ditentukan di atas, yaitu kepada 200 karyawan perusahaan. Angket tersebut akan terdiri dari lima jenis pertanyaan dengan komposisi pertanyaan masing-masing sebagai berikut:

1. Pertanyaan mengenai motivasi sebanyak 10 pertanyaan

2. Pertanyaan mengenai disiplin sebanyak 10 pertanyaan

3. Pertanyaan mengenai kepuasan kerja sebanyak 10 pertanyaan

4. Pertanyaan mengenai iklim perusahaan sebanyak 10 pertanyaan.

5. Pertanyaan mengenai kinerja karyawan sebanyak 12 pertanyaan.

\section{E. Teknik Analisis Instrumen}

Menurut Arikunto (2002:144) instrumen yang baik harus memenuhi dua persyaratan penting, yaitu valid dan reliabel. Uji coba instrumen diperlukan untuk mengetahui apakah instrumen yang digunakan tersebut benar-benar sahih dan handal, yang dimaksud valid atau sahih adalah untuk melihat apakah suatu alat ukur tersebut mampu mengukur apa yang hendak diukur, sedangkan yang dimaksud dengan reliabel atau handal adalah untuk melihat apakah suatu alat ukur mampu memberikan hasil pengukuran yang konsisten dalam waktu dan tempat yang berbeda.

\section{Uji kesahihan Instrumen (Validitas)}

Setelah data hasil uji coba terkumpul, data tersebut dianalisis agar dapat membedakan butir-butir yang memenuhi syarat untuk dipilih menjadi instrumen dan untuk dilakukan analisis data yang membuktikan tingkat validitas dengan alat bantu komputer yaitu dengan program SPSS 21 dan Excel. Jika butir soal yang dinyatakan gugur, tidak mempengaruhi keterwakilan butir-butir untuk setiap indikator untuk masing-masing variabel, maka butir yang gugur tersebut dikeluarkan dari instrumen karena butir yang sahih dianggap 
sudah cukup memadai untuk menjaring data yang diperlukan. Untuk menghitung validitas alat-alat ukur dalam penelitian ini digunakan rumus:

$r_{\text {hitung }}=\frac{n\left(\sum X_{1} Y_{1}\right)-\left(\sum Y_{1}\right)}{\sqrt{\left\{n \cdot \sum X_{1}^{2}-\left(X_{1}\right)^{2}\right\} \cdot\left\{n \cdot \sum Y_{1}^{2}-\left(\sum Y_{1}\right)^{2}\right\}}}$

Dimana:

$\mathrm{r}_{\text {hitung }} \quad=$ koefision korelasi

$\mathrm{n}=$ jumlah sampel

$\mathrm{X}=$ skor variabel bebas

$\mathrm{Y}=$ skor variabel terikat

Setelah nilai korelasi $\left(r_{\text {hitung }}\right)$ diperoleh, kemudian nilai $r_{\text {hitung }}$ dibandingkan dengan $\mathrm{r}$ tabel kaidah keputusannya adalah sebagai berikut $\mathrm{r}_{\text {hitung }}>\mathrm{r}_{\text {tabel }}$ maka alat ukur atau instrumen yang digunakan dalam penelitian dinyatakan valid, dan sebaliknya jika $\mathrm{r}_{\text {hitung }}<\mathrm{r}_{\text {tabel }}$ maka alat ukur atau instrumen yang digunakan tidak valid dengan taraf signifikan $\alpha=0,05$. Pendapat lain yaitu, menurut Sugiyono (2012:179), bila korelasi tiap faktor $\left(r_{x y}\right)$ tersebut positif dan besarnya $>0,30$ maka faktor tersebut merupakan construct yang kuat atau valid, demikian pula sebaliknya jika $r_{x y}<0,30$ maka dikatakan tidak valid. Dalam penelitian ini penulis menggunakan pendapat kedua yaitu pendapat Sugiyono, dimana variabel dikatakan valid bila nilai $r_{\text {hitung }}$ lebih besar dari 0,30 ( $\left.\mathrm{r}_{\text {hitung }}>0,30\right)$.

\section{a) Variabel Motivasi}

Berdasarkan tabel di bawah (Tabel 14) dapat diketahui bahwa 10 sampel kuesioner variabel motivasi (di luar dari sampel penelitian) diambil sebagai sampel uji validitas instrumen dan hasilnya semua $r_{\text {hitung }}$ nilainya lebih besar dari 0,30 ( $r_{\text {hitung }}>$ 0,30), sehingga dapat disimpulkan semua pertanyaan variabel motivasi dinyatakan valid. 
Tabel 14. Hasil Uji Validitas variabel Motivasi

\begin{tabular}{|c|c|c|c|c|}
\hline Pertanyaan & $\mathrm{N}$ & $r_{\text {hitung }}$ & kondisi & Keterangan \\
\hline Q1 & 10 & 0,534 & $\mathrm{r}_{\text {hitung }}>0,30$ & Valid \\
\hline Q2 & 10 & 0,798 & $\mathrm{r}_{\text {hitung }}>0,30$ & Valid \\
\hline Q3 & 10 & 0,649 & $\mathrm{r}_{\text {hitung }}>0,30$ & Valid \\
\hline Q4 & 10 & 0,709 & $\mathrm{r}_{\text {hitung }}>0,30$ & Valid \\
\hline Q5 & 10 & 0,407 & $\mathrm{r}_{\text {hitung }}>0,30$ & Valid \\
\hline Q6 & 10 & 0,801 & $\mathrm{r}_{\text {hitung }}>0,30$ & Valid \\
\hline Q7 & 10 & 0,790 & $\mathrm{r}_{\text {hitung }}>0,30$ & Valid \\
\hline Q8 & 10 & 0,355 & $\mathrm{r}_{\text {hitung }}>0,30$ & Valid \\
\hline Q9 & 10 & 0,484 & $\mathrm{r}_{\text {hitung }}>0,30$ & Valid \\
\hline Q10 & 10 & 0,425 & $\mathrm{r}_{\text {hitung }}>0,30$ & Valid \\
\hline
\end{tabular}

Sumber: Data olahan, 2019.

\section{b) Variabel Disiplin}

Berdasarkan tabel di bawah (Tabel 15) dapat diketahui bahwa 10 sampel kuesioner variabel disiplin (di luar dari sampel penelitian) diambil sebagai sampel uji validitas instrumen dan hasilnya semua $r_{\text {hitung }}$ nilainya lebih besar dari 0,30 ( $r_{\text {hitung }}>$ 0,30), sehingga dapat disimpulkan semua pertanyaan variabel motivasi dinyatakan valid. 
Tabel 15. Hasil Uji Validitas variabel Disiplin

\begin{tabular}{|c|c|c|c|c|}
\hline Pertanyaan & $\mathrm{N}$ & $r_{\text {hitung }}$ & kondisi & Keterangan \\
\hline Q1 & 10 & 0,853 & $\mathrm{r}_{\text {hitung }}>0,30$ & Valid \\
\hline Q2 & 10 & 0,772 & $\mathrm{r}_{\text {hitung }}>0,30$ & Valid \\
\hline Q3 & 10 & 0,657 & $\mathrm{r}_{\text {hitung }}>0,30$ & Valid \\
\hline Q4 & 10 & 0,549 & $\mathrm{r}_{\text {hitung }}>0,30$ & Valid \\
\hline Q5 & 10 & 0,753 & $\mathrm{r}_{\text {hitung }}>0,30$ & Valid \\
\hline Q6 & 10 & 0,784 & $\mathrm{r}_{\text {hitung }}>0,30$ & Valid \\
\hline Q7 & 10 & 0,883 & $\mathrm{r}_{\text {hitung }}>0,30$ & Valid \\
\hline Q8 & 10 & 0,867 & $\mathrm{r}_{\text {hitung }}>0,30$ & Valid \\
\hline Q9 & 10 & 0,655 & $\mathrm{r}_{\text {hitung }}>0,30$ & Valid \\
\hline Q10 & 10 & 0,498 & $\mathrm{r}_{\text {hitung }}>0,30$ & Valid \\
\hline
\end{tabular}

Sumber: Data olahan, 2019.

c) Variabel Kepuasan Kerja

Tabel 16. Hasil Uji Validitas variabel Kepuasan Kerja

\begin{tabular}{|c|c|c|c|c|}
\hline Pertanyaan & $\mathrm{N}$ & $r_{\text {hitung }}$ & kondisi & Keterangan \\
\hline Q1 & 10 & 0,902 & $\mathrm{r}_{\text {hitung }}>0,30$ & Valid \\
\hline Q2 & 10 & 0,916 & $\mathrm{r}_{\text {hitung }}>0,30$ & Valid \\
\hline Q3 & 10 & 0,891 & $\mathrm{r}_{\text {hitung }}>0,30$ & Valid \\
\hline Q4 & 10 & 0,456 & $\mathrm{r}_{\text {hitung }}>0,30$ & Valid \\
\hline Q5 & 10 & 0.701 & $\mathrm{r}_{\text {hitung }}>0,30$ & Valid \\
\hline Q6 & 10 & 0,841 & $\mathrm{r}_{\text {hitung }}>0,30$ & Valid \\
\hline Q7 & 10 & 0,931 & $\mathrm{r}_{\text {hitung }}>0,30$ & Valid \\
\hline Q8 & 10 & 0,620 & $\mathrm{r}_{\text {hitung }}>0,30$ & Valid \\
\hline Q9 & 10 & 0,680 & $\mathrm{r}_{\text {hitung }}>0,30$ & Valid \\
\hline Q10 & 10 & 0,872 & $\mathrm{r}_{\text {hitung }}>0,30$ & Valid \\
\hline
\end{tabular}

Sumber: Data olahan, 2019.

Berdasarkan tabel di atas (Tabel 16) dapat diketahui bahwa 10 sampel kuesioner variabel motivasi (di luar dari sampel penelitian) diambil sebagai sampel uji validitas instrumen dan 
hasilnya semua $r_{\text {hitung }}$ nilainya lebih besar dari 0,30 ( $r_{\text {hitung }}>$ 0,30), sehingga dapat disimpulkan semua pertanyaan variabel motivasi dinyatakan valid.

\section{d) Variabel Iklim Perusahaan}

Tabel 17. Hasil Uji Validitas variabel Iklim Perusahaan

\begin{tabular}{|c|c|c|c|c|}
\hline Pertanyaan & $\mathrm{N}$ & $r_{\text {hitung }}$ & kondisi & Keterangan \\
\hline Q1 & 10 & 0,937 & $\mathrm{r}_{\text {hitung }}>0,30$ & Valid \\
\hline Q2 & 10 & 0,648 & $\mathrm{r}_{\text {hitung }}>0,30$ & Valid \\
\hline Q3 & 10 & 0,785 & $\mathrm{r}_{\text {hitung }}>0,30$ & Valid \\
\hline Q4 & 10 & 0,734 & $\mathrm{r}_{\text {hitung }}>0,30$ & Valid \\
\hline Q5 & 10 & 0,703 & $\mathrm{r}_{\text {hitung }}>0,30$ & Valid \\
\hline Q6 & 10 & 0,528 & $\mathrm{r}_{\text {hitung }}>0,30$ & Valid \\
\hline Q7 & 10 & 0,781 & $\mathrm{r}_{\text {hitung }}>0,30$ & Valid \\
\hline Q8 & 10 & 0,567 & $\mathrm{r}_{\text {hitung }}>0,30$ & Valid \\
\hline Q9 & 10 & 0,486 & $\mathrm{r}_{\text {hitung }}>0,30$ & Valid \\
\hline Q10 & 10 & 0,397 & $\mathrm{r}_{\text {hitung }}>0,30$ & Valid \\
\hline
\end{tabular}

Sumber: Data olahan, 2019.

Berdasarkan tabel di atas (Tabel 17) dapat diketahui bahwa 10 sampel kuesioner variabel iklim perusahaan (di luar dari sampel penelitian) diambil sebagai sampel uji validitas instrumen dan hasilnya semua $r_{\text {hitung }}$ nilainya lebih besar dari $0,30\left(r_{\text {hitung }}>\right.$ 0,30), sehingga dapat disimpulkan semua pertanyaan variabel iklim perusahaan dinyatakan valid.

e) Variabel Kinerja Karyawan

Berdasarkan tabel di bawah (Tabel 18) dapat diketahui bahwa 10 sampel kuesioner variabel kinerja karyawan (di luar dari sampel penelitian) diambil sebagai sampel uji validitas instrumen dan hasilnya semua $r_{\text {hitung }}$ nilainya lebih besar dari $0,30\left(r_{\text {hitung }}>\right.$ $0,30)$, sehingga dapat disimpulkan semua pertanyaan variabel kinerja karyawan dinyatakan valid. 
Tabel 18. Hasil Uji Validitas variabel Kinerja Karyawan

\begin{tabular}{|c|c|c|c|c|}
\hline Pertanyaan & $\mathrm{N}$ & $r_{\text {hitung }}$ & kondisi & Keterangan \\
\hline Q1 & 10 & 0,493 & $\mathrm{r}_{\text {hitung }}>0,30$ & Valid \\
\hline Q2 & 10 & 0,773 & $\mathrm{r}_{\text {hitung }}>0,30$ & Valid \\
\hline Q3 & 10 & 0,531 & $\mathrm{r}_{\text {hitung }}>0,30$ & Valid \\
\hline Q4 & 10 & 0,702 & $\mathrm{r}_{\text {hitung }}>0,30$ & Valid \\
\hline Q5 & 10 & 0,411 & $\mathrm{r}_{\text {hitung }}>0,30$ & Valid \\
\hline Q6 & 10 & 0,613 & $\mathrm{r}_{\text {hitung }}>0,30$ & Valid \\
\hline Q7 & 10 & 0,745 & $\mathrm{r}_{\text {hitung }}>0,30$ & Valid \\
\hline Q8 & 10 & 0,338 & $\mathrm{r}_{\text {hitung }}>0,30$ & Valid \\
\hline Q9 & 10 & 0,384 & $\mathrm{r}_{\text {hitung }}>0,30$ & Valid \\
\hline Q10 & 10 & 0,552 & $\mathrm{r}_{\text {hitung }}>0,30$ & Valid \\
\hline Q11 & 10 & 0,762 & $\mathrm{r}_{\text {hitung }}>0,30$ & Valid \\
\hline Q12 & 10 & 0,434 & $\mathrm{r}_{\text {hitung }}>0,30$ & Valid \\
\hline
\end{tabular}

Sumber: Data olahan, 2019.

\section{Uji Kehandalan Instrumen (Reliabilitas)}

Uji reliabilitas dalam suatu penelitian sangat perlu dilakukan karena reliabilitas berkaitan dengan taraf 'keajegan' dan taraf kepercayaan terhadap instrumen tersebut. Suatu alat ukur dikatakan memiliki reliabilitas atau keajegan yang tinggi atau dapat dipercaya, apabila alat ukur tersebut stabil (ajeg) sehingga dapat diandalkan dan dapat digunakan untuk meramalkan hasil. Uji reliabilitas digunakan untuk menguji sejauh mana konsistensi hasil pengukuran yang dilakukan. Kehandalan instrumen dilakukan dengan menggunakan rumus Alpha Cronbach dengan menggunakan sarana komputer program SPSS 21. Langkah-langkah dalam mencari reliabilitas dengan metode Alpha Cronbach adalah dengan menggunakan rumus sebagai berikut:

$\alpha=2\left(\frac{S_{1}{ }^{2}-S_{2}{ }^{2}}{S_{x}{ }^{2}}\right)$ 
Keterangan:

$\alpha=$ Reliabilitas Instrumen

$S_{1}{ }^{2}=$ Varians skor belahan pertama

$S_{2}{ }^{2}=$ Varians skor belahan kedua

$S_{x}{ }^{2}=$ Varians skor total

Nilai reliabilitas dinyatakan dengan koefisien Alpha Cronbach berdasarkan kriteria batas terendah reliabilitas adalah 0,6. Jadi bila kriteria itu dipenuhi maka kuesioner dinyatakan reliable. Hasil uji reliabilitas variabel motivasi $\left(\mathrm{X}_{1}\right)$, disiplin $\left(\mathrm{X}_{2}\right)$, kepuasan kerja $\left(\mathrm{X}_{3}\right)$, iklim perusahaan $\left(\mathrm{X}_{4}\right)$ dan kinerja karyawan $(\mathrm{Y})$

Tabel 19. Hasil Pengujian Reliabilitas

\begin{tabular}{|c|c|c|c|c|}
\hline \multicolumn{2}{|c|}{ Variabel } & $\begin{array}{c}\text { Cronbach's } \\
\text { Alpha }\end{array}$ & Kondisi & Keterangan \\
\hline Motivasi & $\mathrm{X}_{1}$ & 0,857 & $\alpha>0,6$ & Reliabel \\
\hline Disiplin & $\mathrm{X}_{2}$ & 0,885 & $\alpha>0,6$ & Reliabel \\
\hline Kepuasan Kerja & $\mathrm{X}_{3}$ & 0,886 & $\alpha>0,6$ & Reliabel \\
\hline Iklim Perusahaan & $\mathrm{X}_{4}$ & 0,894 & $\alpha>0,6$ & Reliabel \\
\hline Kinerja Karyawan & $\mathrm{Y}$ & 0,834 & $\alpha>0,6$ & Reliabel \\
\hline
\end{tabular}

Sumber: Data Olahan, 2019.

Untuk mengetahui bagaimana derajat reliabilitas diklasifikasikan sebagai tabel berikut:

\section{Tabel 20. Derajat Reliabilitas}

\begin{tabular}{|c|c|}
\hline Besarnya nilai $\mathrm{r}$ & Interpretasi \\
\hline Antara 0,80 sampai 1.00 & Tinggi \\
\hline Antara 0,60 sampai 0.80 & Cukup \\
\hline Antara 0,40 sampai 0,60 & Rendah \\
\hline Antara 0,20 sampai 0,40 & Sangat rendah \\
\hline Antara 0,00 sampai 0,20 & Tidak berkolerasi \\
\hline
\end{tabular}

Sumber: Data olahan, 2019. 


\section{F. Teknik Analisis Data}

Teknik analisis data yang akan digunakan adalah uji persyaratan parametrik dan uji hipotesis. Adapun uji persyaratan parametrik atau uji asumsi klasik meliputi: 1) uji normalitas, 2) uji linearitas, 3) uji autokorelasi, 4) uji multikolinearitas, dan 5) uji heteroskedastisitas, berikut ini adalah penjelasan masing-masing pengujian tersebut.

\section{Uji Asumsi Klasik}

\section{a. Uji Normalitas}

Pengujian normalitas data digunakan untuk dilakukan terhadap semua variabel yang diteliti, yaitu meliputi variabel motivasi $\left(\mathrm{X}_{1}\right)$, disiplin $\left(\mathrm{X}_{2}\right)$, kepuasan kerja $\left(\mathrm{X}_{3}\right)$, iklim perusahaan $\left(\mathrm{X}_{4}\right)$ dan kinerja karyawan $(\mathrm{Y})$. Hasil pengujian terhadap sample penelitian digunakan untuk menyimpulkan apakah populasi yang diamati berdistribusi normal atau tidak. Apabila pengujian normal, maka hasil perhitungan statistik dapat digeneralisasikan pada populasinya. Uji normalitas dilakukan dengan baik secara manual maupun menggunakan komputer program SPSS. Dalam penelitian ini, uji normalitas dapat digunakan uji kolmogorov $>0,05$ berarti berdistribusi normal.

Untuk keperluan pengujian normal tidaknya distribusi masing-masing data dirumuskan hipotesis sebagai berikut: Ho : Data berasal dari sampel tidak berdistribusi normal Ha : Data berasal dari sampel berdiskusi normal Kriteria uji tolak Ho jika nilai sig. 0,05 dan diterima Ho untuk selainnya.

\section{b. Uji Linearitas}

Uji linearitas dilakukan dengan menggunakan tabel Anova, yaitu dengan menguji:

1) Uji linearitas pengaruh $X_{1}$ terhadap $Y$

2) Uji linearitas pengaruh $X_{2}$ terhadap $Y$

3) Uji linearitas pengaruh $X_{3}$ terhadap $Y$ 
4) Uji linearitas pengaruh $X_{4}$ terhadap $Y$

Dengan demikian pengaruh langsung atau tidak langsung dari variabel eksogen (bebas) terhadap variabel endogen (terikat) dapat diketahui dengan melihat koefisien jalur. Adapun persyaratan koefisien jalur adalah:

a) Hubungan antara dua variabel merupakan hubungan linear, adiktif dan kasual.

b) Sistem menganut prinsip satu arah (rekrusif)

c) Masing-masing variabel residu tidak saling berkorelasi dengan variabel penyebab.

d) Masing-masing variabel berupa data kuantum.

\section{c. Uji Autokorelasi}

Menurut Sujarweni (2015:186) uji autokorelasi bertujuan untuk mengetahui ada tidaknya korelasi antara variabel pengganggu pada periode tertentu dengan variabel sebelumnya. Cara mendeteksi autokorelasi adalah dengan membandingkan nilai Durbin Watson (DW) dengan tabel Durbin Watson ( $d u$ dan $d l)$ sebagai berikut:

$\mathrm{DW}<\mathrm{dl} \quad=$ ada autokorelasi positif

$\mathrm{dl}<\mathrm{DW}<\mathrm{du} \quad=$ tanpa kesimpulan $($ ragu-ragu)

$\mathrm{du}<\mathrm{DW}<4-\mathrm{du} \quad=$ bebas autokorelasi

4-du $<$ DW $<4$-dl = tanpa kesimpulan (ragu-ragu)

$\mathrm{DW}>4-\mathrm{dl} \quad=$ ada autokorelasi negatif

\section{d. Uji Multikolinearitas}

Uji multikolinieritas bertujuan untuk menguji apakah model regresi ditemukan adanya hubungan yang kuat di antara variabel independen. Sujarweni (2015:185), mengemukakan cara untuk mengetahui ada tidaknya multikolinieritas, yaitu dengan melihat besarnya nilai toleransi value atau Variance Inflation Factor (VIF). Apabila nilai VIF lebih kecil dari satu atau lebih besar dari 10 maka terjadi multikolinieritas, sebaliknya bila tidak terjadi 
multikolinieritas antar variabel independen maka nilai VIF akan berada pada kisaran 1 sampai 10.

\section{e. Uji Heteroskedastisitas}

Uji heteroskedastisitas bertujuan untuk menguji terjadinya perbedaan variance residual suatu periode pengamatan ke periode pengamatan yang lain. Cara memprediksi ada tidaknya heteroskedastisitas pada suatu model dapat dilihat dengan pola gambar scatterplot, regresi yang tidak terjadi heteroskedastisitas jika:

1) Titik-titik data menyebar di atas dan di bawah atau di sekitar angka nol.

2) Titik-titik data tidak mengumpul hanya di atas atau di bawah saja.

3) Penyebaran titik-titik data tidak boleh membentuk pola bergelombang melebar kemudiaan menyempit dan melebar kembali.

4) Penyebaran titik-titik data tidak berpola.

\section{Uji Hipotesis}

\section{a. Persamaan Regresi Linier Sederhana (Uji t)}

Uji regresi linier sederhana atau uji korelasi tunggal atau juga disebut uji $\mathrm{t}$, digunakan untuk menguji hipotesis pertama dan kedua. Teknik korelasi sederhana yang digunakan adalah korelasi pearson. Hal ini dimaksudkan untuk mengetahui hubungan antara variabel-variabel bebas dan terikatnya.

Untuk menguji apakah korelasi signifikan atau tidak, diuji dengan menggunakan uji $\mathrm{t}$ dengan rumus (Irianto, 2009:105,146):

$$
t=\frac{\sqrt[r]{n-2}}{\sqrt{1-r^{2}}}
$$


Kemudian dilanjutkan dengan menghitung persamaan regresinya untuk memprediksi seberapa tinggi nilai variabel dependen bila nilai variabel independen dimanipulasi.

Pengujian secara individu ini membuktikan bahwa koefisien regresi suatu model itu statistik signifikan atau tidak, maka dipakai uji t, adapun langkah-langkahnya sebagai berikut:

1) Perumusan hipotesis

a) Ho : $\beta_{1}=\beta_{2}=\beta_{3}=\beta_{4}=0$, artinya tidak ada pengaruh yang signifikan antara varuabel $\mathrm{X}_{1}, \mathrm{X}_{2}, \mathrm{X}_{3}, \mathrm{X}_{4}$ terhadap variabel $\mathrm{Y}$.

b) $\mathrm{Ha}: \beta_{1} \neq \beta_{2} \neq \beta_{3} \neq \beta_{4} \neq 0$, artinya ada pengaruh yang signifikan antara variabel $\mathrm{X}_{1}, \mathrm{X}_{2}, \mathrm{X}_{3}, \mathrm{X}_{4}$ terhadap variabel Y.

2) Menentukan level signifikansi $\alpha=0,05$

3) Nilai t hitung

$t=\frac{b-\beta}{S e b}$

Dimana:

b : koefisien regresi

Seb : Standard error b

Selanjutnya untuk menguji hipotesis dengan ketentuan sebagai berikut:

Pengaruh $X_{1}, X_{2}, X_{3}$ dan $X_{4}$ terhadap $Y$ secara parsial (uji t)

1) Ho : $\rho=0$, artinya $X_{1}, X_{2}, X_{3}$ dan $X_{4}$ secara parsial (sendiri-sendiri) tidak berpengaruh secara signifikan terhadap Y.

2) Ha $: \rho \neq 0$, artinya $X_{1}, X_{2}, X_{3}$ dan $X_{4}$ secara parsial (sendiri-sendiri) berpengaruh secara signifikan terhadap Y.

Kaidah pengambilan keputusan: 
a) Jika Sig. $t_{\text {hitung }}>$ Sig. $t_{\text {tabel }}$ maka Ho ditolak

b) Jika Sig. $t_{\text {hitung }}<$ Sig. $t_{\text {tabel }}$ maka Ho diterima

\section{b. Analisis Korelasi Product Moment Dua Variabel}

Menurut Arikunto (Arikunto, 2002:376) bahwa analisis korelasi product moment dua variabel digunakan untuk menganalisis atau mengetahui hubungan antara variabel bebas dengan variabel terikatnya. Rumus yang digunakan adalah:

Korelasi antara variabel $\mathrm{X}$ dengan variabel $\mathrm{Y}$ dengan rumus korelasi Pearson Product Moment adalah:

$$
r_{\text {hitung }}=\frac{n\left(\sum X_{1} Y_{1}\right)-\left(\sum X_{1}\right)\left(\sum Y_{1}\right)}{\sqrt{\left\{n \cdot \sum X_{1}^{2}-\left(X_{1}\right)^{2}\right\}} \cdot\left\{n \cdot \sum Y_{1}^{2}-\left(\sum Y_{1}\right)^{2}\right\}}
$$

Dimana:

$$
\begin{array}{ll}
\mathrm{r}_{\text {hitung }} & =\text { koefisien korelasi } \\
\mathrm{n} & =\text { jumlah sampel } \\
\mathrm{X} & =\text { skor variabel bebas } \\
\mathrm{Y} & =\text { skor variabel terikat }
\end{array}
$$

Persamaan garis regresi sederhana (dengan satu prediktor) adalah:

$\mathrm{Y}=\mathrm{a}+\mathrm{bX}$

\section{Keterangan:}

$\mathrm{Y} \quad=$ Nilai yang diprediksi (variabel terikat)

a = Harga bilangan konstan

$\mathrm{b}=$ Harga koefisien prediktor

$\mathrm{X}=$ Nilai variabel bebas

Untuk mencari nilai a dan b digunakan rumus:

$$
\begin{aligned}
& a=\frac{\left(\sum Y\right) \cdot\left(\sum X^{2}\right) \cdot\left(\sum X\right) \cdot\left(\sum X Y\right)}{n\left(\sum X^{2}\right)-\left(\sum X\right)^{2}} \\
& b=\frac{n\left(\sum X Y\right)-\left(\sum X\right) \cdot\left(\sum Y\right)}{n\left(\sum X^{2}\right)-\left(\sum X\right)^{2}}
\end{aligned}
$$




\section{c. Persamaan Regresi Berganda (Uji F)}

Uji korelasi berganda atau persamaan regresi berganda digunakan untuk melihat apakah terdapat korelasi antara variabel bebas secara bersama-sama dengan variabel terikatnya. Koefisien korelasi antara kriterium $\mathrm{Y}$ dengan prediktor X1, X2. X3 dan X4 dapat diperoleh dengan rumus (Budiyono, 2009:282):

$$
R_{y(1,2)}=\frac{\sqrt{a_{1} \sum x_{1} y+a_{2} \sum x_{2} y+a_{3} \sum x_{3} y+a_{4} \sum x_{4} y}}{\sum Y^{2}}
$$

Keterangan:

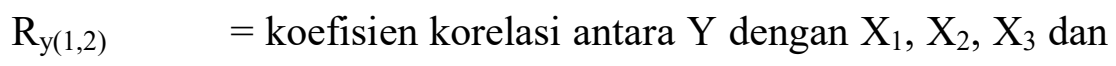
$\mathrm{X}_{4}$

$\mathrm{X} 1 \mathrm{Y}=$ jumlah produk antara $\mathrm{X}_{1}$ dengan $\mathrm{Y}$

$\mathrm{X} 2 \mathrm{Y}=$ jumlah produk antara $\mathrm{X}_{2}$ dengan $\mathrm{Y}$

$\mathrm{X} 3 \mathrm{Y}=$ jumlah produk antara $\mathrm{X}_{3}$ dengan $\mathrm{Y}$

$\mathrm{X} 4 \mathrm{Y}=$ jumlah produk antara $\mathrm{X}_{4}$ dengan $\mathrm{Y}$

$\Sigma \mathrm{Y}^{2} \quad=$ jumlah kuardrat kriterium $\mathrm{Y}$

$\mathrm{a}(1,2)=$ koefisien prediktor

Untuk menguji apakah korelasi signifikan atau tidak digunakan rumus:

$F_{\text {reg }}=\frac{R^{2}(N-m-1)}{\left(1-R^{2}\right) m}$

Keterangan:

$\mathrm{N}=$ jumlah kasus

$\mathrm{m}=$ jumlah prediktor

$\mathrm{R}=$ koefisien korelasi antara interium dengan prediktorprediktor

Kemudian dilanjutkan dengan menghitung persamaan regresi berganda dengan rumus:

$\mathbf{Y}=\mathbf{a}+\mathbf{b}_{1} \mathbf{X}_{1}+\mathbf{b}_{2} \mathbf{X}_{2}+\mathbf{b}_{3} \mathbf{X}_{3}+\mathbf{b}_{4} \mathbf{X}_{4}$

Dimana:

$\mathrm{Y} \quad=$ variabel kinerja karyawan 


$$
\begin{array}{ll}
\mathrm{X}_{1} & =\text { variabel motivasi } \\
\mathrm{X}_{2} & =\text { variabel disiplin } \\
\mathrm{X}_{3} & =\text { variabel kepuasan kerja } \\
\mathrm{X}_{4} & =\text { variabel iklim perusahaan } \\
\mathrm{a} & =\text { konstanta } \\
\mathrm{b}_{1}, \mathrm{~b}_{2}, \mathrm{~b}_{3}, \mathrm{~b}_{4} & =\text { koefisien regresi yang dihitung }
\end{array}
$$

Setelah itu dilanjutkan dengan menguji hipotesis dengan ketentuan sebagai berikut:

Pengaruh $\mathrm{X}_{1}, \mathrm{X}_{2}, \mathrm{X}_{3}$ dan $\mathrm{X}_{4}$ terhadap $\mathrm{Y}$ secara simultan (uji F)

1) Ho : $\rho=0$, artinya $X_{1}, X_{2}, X_{3}$ dan $X_{4}$ secara simultan (bersama-sama) tidak berpengaruh secara signifikan terhadap Y.

2) $\mathrm{Ha}: \rho \neq 0$, artinya $X_{1}, X_{2}, X_{3}$ dan $X_{4}$ secara simultan (bersama-sama) berpengaruh secara signifikan terhadap Y. Kaidah pengambilan keputusannya adalah sebagai berikut:

a) Jika Sig. $F_{\text {hitung }}>$ Sig. $F_{\text {tabel }}$, maka Ho ditolak

b) Jika Sig. $F_{\text {hitung }}<$ Sig. $F_{\text {tabel}}$, maka Ho diterima

\section{d. Uji Signifikansi Regresi}

Pengujian tingkat keberartian regresi yang didapat, dilakukan dengan uji t untuk persamaan regresi linier sederhana dan uji $\mathrm{F}$ untuk persamaan regresi linier berganda. Hipotesis yang dilakukan dalam uji ini adalah:

Ho : Persamaan regresi tidak signifikan

Ha : Persamaan regresi signifikan

Kriteria uji yang digunakan untuk uji t pada taraf signifikan 0,05 adalah Ho ditolak jika nilai $t_{\text {hitung }}>t_{\text {tabel, }}$, namun bila terjadi kondisi sebaliknya maka Ho diterima. Sedangkan untuk uji F pada taraf signifikansi 0,05 adalah Ho ditolak jika nilai $F_{\text {hitung }}>$ $\mathrm{F}_{\text {tabel}}$, namun bila terjadi kondisi sebaliknya maka Ho diterima. 


\section{BAB V \\ PENUTUP}

\section{A. Kesimpulan}

Penelitian ini bertujuan untuk mengetahui pengaruh motivasi, disiplin, kepuasan kerja dan iklim perusahaan dan pengaruhnya terhadap kinerja karyawan. Dalam penelitian ini motivasi, disiplin, kepuasan kerja dan iklim perusahaan merupakan variabel bebas yang diduga mempunyai hubungan dan pengaruh terhadap kinerja karyawan. Dari hasil penelitian yang telah dijabarkan dalam bab-bab sebelumnya maka didapati kesimpulan sebagai berikut:

1. Motivasi berpengaruh secara signifikan terhadap kinerja karyawan pada PT. Profab Indonesia.

2. Disiplin berpengaruh secara signifikan terhadap kinerja karyawan pada PT. Profab Indonesia.

3. Kepuasan kerja berpengaruh secara signifikan terhadap kinerja karyawan pada PT. Profab Indonesia.

4. Iklim perusahaan berpengaruh secara signifikan terhadap kinerja karyawan pada PT. Profab Indonesia.

5. Motivasi, disiplin, kepuasan kerja dan iklim perusahaan secara bersama-sama berpengaruh secara signifikan terhadap kinerja karyawan pada PT. Profab Indonesia.

\section{B. Saran}

Berdasarkan kesimpulan yang telah diuraikan di atas, maka perlu disarankan hal-hal berikut:

1. Penelitian ini dapat dikembangkan oleh praktisi dan akademisi sebagai bahan masukan untuk merancang dan merencanakan proses peningkatan kinerja perusahaan dengan mengumpulkan bukti-bukti empiris dan sekunder sehingga diperoleh data yang lebih akurat. 
2. Perlu terus dilakukan penelitian-penelitian yang sama di perusahaanperusahaan yang sejenis sehingga dapat diperoleh benchmarking trend dari penelitian ini.

3. Keterbatasan yang masih menjadi kendala dalam penelitian ini adalah, kesulitan dalam mengumpulkan data sesuai jadwal. Kesibukan responden sebagai karyawan membutuhkan usaha yang lebih bagi peneliti untuk mengumpulkan hasil penelitian.

4. Kekurangan-kekurangan yang lain adalah belum banyak tersedianya bahan pustaka tentang Sumber Daya Manusia dan teori-teorinya di perpustakaan daerah di luar kampus, sehingga penulis banyak bergantung pada perpustakaan kampus dan pustaka daring (on-line).

5. Penelitian-peneltian yang sama di perusahaan atau lokasi yang sama masih mungkin dilakukan dengan mengembangkan variabel-variabel yang lain yang mungkin memberikan pengaruh yang lebih signifikan terhadap variabel kinerja karyawan daripada variabel-variabel bebas yang telah dibahas dalam penelitian ini. 


\section{DAFTAR PUSTAKA}

Arikunto, S. 2002. Prosedur Penelitian Suatu Pendekatan Praktek. Jakarta: Rineka Cipta.

Badeni. 2013. Kepemimpinan dan Perilaku Organisasi. Bandung: Alfabeta.

Bianca, A., Susihono W. 2012. Pengaruh Iklim Organisasi Dan Pengembangan Karir Terhadap Kepuasan Kerja Karyawan. Jurnal Spektrum Industri, Volume. 10, No. 2.

Budiyono. 2009. Statistika Untuk Penelitian Edisi Ke-2. Surakarta: Universitas Sebelas Maret Press.

Dantes, N. 2012. Metode Penelitian. Yogyakarta: ANDI.

Gathungu, James, Wachira, H.W. 2013. Job Satisfaction Factors that Influence the Performance of Secondary School Principals in their Administrative Functions in Mombasa District, Kenya. International Journal of Education and Research. Vol. 1 No 2, pp. 257-270.

Hariandja, M.T.E. 2009. Manajemen Sumber Daya Manusia - Pengadaan, Pengembangan, Pengkompensasian, dan Peningkatan Produktivitas Pegawai. Cetakan ke-5. Jakarta: PT. Grasindo.

Handoko T, Hani. 2014. Manajemen Personalia dan Sumber Daya Manusia. Yogyakarta: BPFE.

Hasibuan, M.S.P. 2016. Manajemen Sumber Daya Manusia. Cetakan ke-20. Jakarta: Bumi Aksara.

Irianto, A. 2009. Statistik Konsep Dasar dan Aplikasinya. Jakarta: Kencana Prenada Media Grup.

Isbahi, M.F. 2013. Pengaruh Motivasi Kerja dan Iklim Organisasi Terhadap Kinerja Guru SD Negeri Se-Kecamatan Rembang, Kabupaten Rembang. Skripsi. Fakultas Ilmu Pendidikan. Universitas Negeri Yogyakarta.

Juniantara, I.W., Riana, I.G. 2015. Pengaruh Motivasi dan Kepuasan Kerja Terhadap Kinerja Karyawan Koperasi di Denpasar. E-jurnal Ekonomi dan Bisnis Universitas Udayana 4.09, ISSN: 2337-3067, hal: 611-628.

Khasifah, F. Nugraheni, R. 2016. Pengaruh Disiplin Kerja, Beban Kerja dan 
Lingkungan Kerja Terhadap Kinerja Pegawai - Studi Pada Balai Besar Wilayah Sungai Pemali Juana. Diponegoro Journal of Management, ISSN(e): 2337-3792. Vol. 5, No. 1, Hal. 1-7.

Mariam, R. 2009. Pengaruh Gaya Kepemimpinan dan Budaya Organisasi Terhadap Kinerja Karyawan Melalui Kepuasan Kerja Karyawan Sebagai Variabel Intervening - Studi pada Kantor Pusat PT. Asuransi Jasa Indonesia (Persero). Tesis. Prodi Magister Manajemen. Universitas Diponegoro, Semarang.

Musfiqon. 2012. Metodologi Penelitian Pendidikan. Jakarta: Prestasi Pustaka Jaya.

Nazir, M. 2014. Metode Penelitian. Cetakan Ke-10. Bogor: Ghalia Indonesia.

Ncube, C.M., Samuel, M.O. 2014. Revisiting Employee Motivation and Job Satisfaction within the Context of an Emerging Economy: Theoretical Representation and Developing the Model. Mediterranean Journal of Social Sciences. Vol. 5, No. 9, pages 267-282.

Noor, J. 2015. Metodologi Penelitian: Skripsi, Tesis, Disertasi, dan Karya Ilmiah. Cetakan ke-5. Jakarta: Prenadamedia Group.

Prawirosentono, S. Primasari, D. 2017. Manajemen Sumber Daya: Kinerja dan Motivasi Karyawan - Membangun Organisasi Kompetitif Era Perdagangan Bebas Dunia. Edisi Ketiga, Cetakan ke-2. Yogyakarta: BPFE.

Priyatno, D. 2017. Panduan Praktis Olah Data Menggunakan SPSS. Yogyakarta: Penerbit Andi.

Robbins, S.P., Coulter, M. 2012. Management. $11^{\text {th }}$ Edition. USA: Pearson Education.

Robbins, S.P., Judge, T.A. 2013. Organizational Behaviour. 15th Edition. USA: Pearson Education.

Ratnasari, S.L. Sutjahjo, G. 2017. Kompensasi, Iklim Organisasi dan Kepuasan Kerja terhadap Kinerja Karyawan PT. PEB. Jurnal Manajemen Bisnis (MEBIS). Prodi Manajemen. Universitas Pembangunan Nasional Veteran. ISSN(e): 2599-283X, pp. 71-75.

Siagian, S.P. 2014. Manajemen Sumber Daya Manusia, Cetakan ke-20. Jakarta: 
Bumi Aksara.

Simanjuntak, P.J. 2011. Manajemen dan Evaluasi Kinerja. Edisi 3. Jakarta: Lembaga Penerbit FEUI.

Siregar, S. 2013. Metode Penelitian Kuantitatif. Jakarta: Kencana Prenada Media Group.

Sugiyono. 2012. Metode Penelitian Kuantitatif dan Kualitatif. Bandung: Alfabeta. Sujarweni, V.W. 2015. SPSS Untuk Penelitian. Yogyakarta: Pustaka Baru Press.

Sukadi. 2016. Hubungan Motivasi Kerja dan Disiplin Kerja Terhadap Kinerja Guru Madrasah Tsanawiyah Al-Huda 1, Karangpandan. Tesis. IAIN Surakarta.

Sulasri, D. Suhardi. 2017. Pengaruh Kepemimpinan, Motivasi dan Kepuasan Kerja Terhadap Kinerja Pegawai Dinas Perhubungan Provinsi Riau. Ejournal Universitas Putera Batam.

Sulistyo, B. 2010. Metode Penelitian. Jakarta: Penaku.

Supomo, R. Nurhayati, E. 2018. Manajemen Sumber Daya Manusia - untuk Mahasiswa dan Umum. Bandung: Yrama Widya.

Suprihati. 2014. Analisis Faktor-Faktor yang Mempengaruhi Kinerja Karyawan Perusahaan Sari Jati di Sragen. Jurnal Paradigma. Vol. 12. No.1.

Susan, R. Gakure, W. Kiraithe, E.K. Waititu, A.G. 2012. Influence of Motivation on Performance in the Public Security Sector with a Focus to the Police in Nairobi, Kenya. International Journal of Business and Social Science Vol. 3 No. 23, pp. 195-204.

Syarif, D. 2015. Teori-Teori Manajemen dan Organisasi - Iklim Organisasi. http://theorymanajemendanorganisasi.blogspot.com/2015/12/iklimorganisasi.html[11 Desember 2015].

Teck Hong, T. Waheed, A. 2011. Herzberg's Motivation-Hygiene Theory and Job Satisfaction in the Malaysian Retail Sector: The Mediating Effect of Love of Money. Sunway University. School of Business 5. Jalan Universiti, Bandar Sunway 46150 Petaling Jaya, Selangor, Malaysia. Asian Academy of Management Journal, Vol. 16, No. 1, pp. 73-94.

Walsa, E. Ratnasari, S. L. 2016. Pengaruh Gaya Kepemimpinan dan Motivasi 
Terhadap Kinerja Karyawan PT. Citra Pembina Pengangkutan Industries Batam. Jurnal EKSEKUTIF, Vol. 13, No. 1. Hal 97-111.

Waluyo, M. 2013. Psikologi Industri. Jakarta: Akademia Permata.

Wibowo. 2017. Manajemen Kinerja. Edisi ke-5. Cetakan ke-12. Jakarta: PT. Rajagrafindo Persada.

Wijayanto, D. 2012. Pengantar Manajemen. Jakarta: PT. Gramedia. 


\section{LAMPIRAN 1}

\section{RIWAYAT HIDUP}

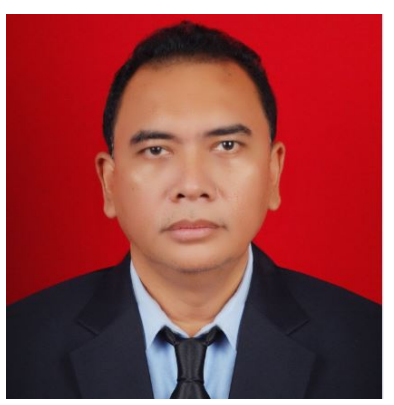

Decky Antony Kifta, Lahir di Jakarta, pada tanggal 3 Desember 1968. Menyelesaikan Pendidikan SD di Jakarta tahun 1981, pendidikan SLTP di SMP Negeri 95 di Jakarta pada tahun 1984, dan pendidikan SLTA di SMA Negeri 75 Jakarta pada tahun 1987. Pada tahun 2012 melanjutkan ke Perguruan Tinggi pada Program Studi Teknik Industri di STT Ibnu Sina Batam, dan memperoleh gelar Sarjana Teknik pada tahun 2016. Bekerja sebagai Quality Manager di PT. Profab Indonesia sejak tahun 2000 hingga sekarang. Ayah dari lima orang anak yaitu: Ridwan Abdul Rauuf, Muhammad Arraafii, Muhammad Rais Arrasyiid, Muhammad Rizqi Arrasyiid dan Nur Amara Zatayumni. 